\title{
RECENT JUDICIAL DEVELOPMENTS OF INTEREST TO OIL AND GAS LAWYERS
}

\author{
Stanley CarsCallen, Q.C., Donald C. Edie, Q.C., \\ ROSA BECK AND VERA A. SLAWINSKI"
}

The purpose of the article is to provide a briefreview of recent Canadian judicial dectsions of interest to oil and gas lawyers. The authors have survejed Canadian case law in the areas of government regulation. conflicts, creditor's rights. surface rights. contracts and tax.
Le but de cet article consiste à fournir un bref aperçu des récentes décisions judiciaires canadiennes interessam les avocats dit domaine petrolier el gazier. Les auseurs ont revu la jurisprudence canodienne dans les domaines de la réglementation gouvernementale, des conflits, des droits des crianciers, des droits de superficie, des contrats et des impóts.

\section{TABLE OF CONTENTS}

1. Administrative LAW .......................... 294

A. Parsaount Resources LTD. V. Alberta (ENERGY AND

UTILITIES BOARD) AND DEVON CANADA V. ALBERTA (ENERGY AND UTILITIES BOARD) ........................ 294

B. DR. $Q$ V. COLLEGE OF PHYSICIANS AND SURGEONS OF BRITISH COLUMBIA ....................... 296

C. LAW SOCIETY OF NEW BRUNSWICK V. RYAN .............. 298

D. ALBERTA (ENERGY RESOURCES CONSERVATION BOARD) V. SARG OILS LTD. . . . . . . . . . . . . . . . . . . . . . 299

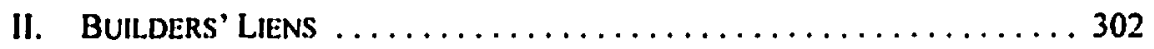

A. PTI GROUP V. ANG GATHERING \& PROCESSING LTD.

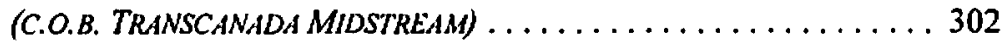

B. TIME SEISMIC EXCHANGE LTD. V. NORTHERN

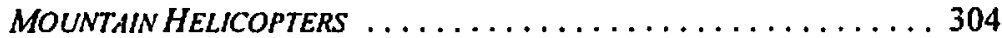

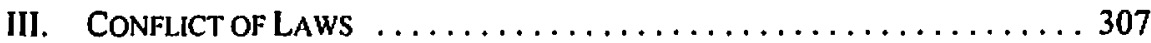

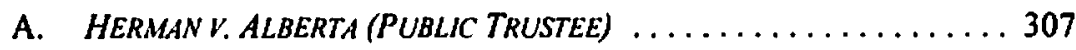

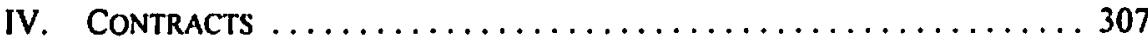

A. AMJ CAMPBELL. V. KORD PRODUCTS .............. 307

B. CANADIAN BROADCASTING CORP. PENSION PLAN

(TRUSTEE OF) V. BF REALTY HOLDINGS LTD. . . . . . . . . . . 309

C. SOLWAYY. DAVIS MOVING \& STORAGE

(C.O.B. KENNEDY MOVING SYSTEMS) .................. 310

D. DEPAR MANAGEMENT LTD. $v$.

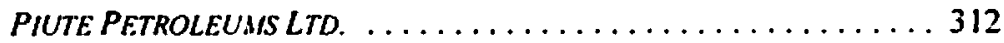



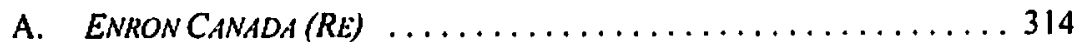

B. BATEX ENERGY LTD. I. ENRON CANADA $\ldots \ldots \ldots \ldots \ldots \ldots \ldots \ldots \ldots$

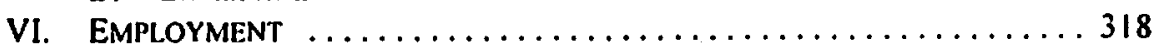

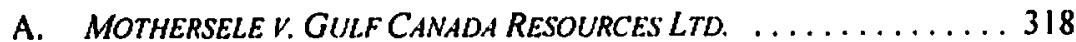

B. VARSITY PLYMOUTH CHRYSLER (1994) LTD. V. POMERLEAU . . . . . 320 


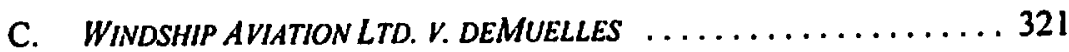

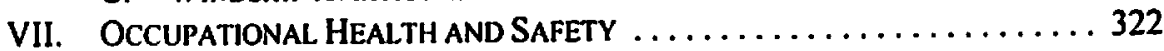

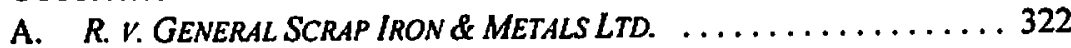

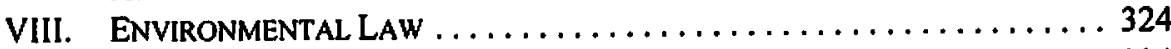

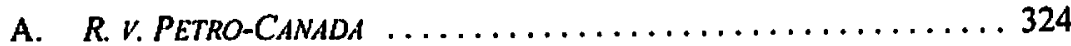

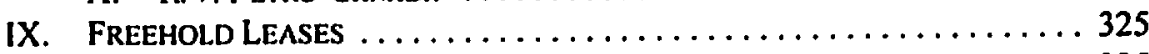

A. FREYBERG V. FLETCHER ChALLENGE OLL AND $G_{A S} \ldots \ldots \ldots \ldots 325$

B. MONTREAL TRUST V. WILIIISTON WILDCATTERS . . . . . . . . . . 329

X. GuaranteEs ............................ 330

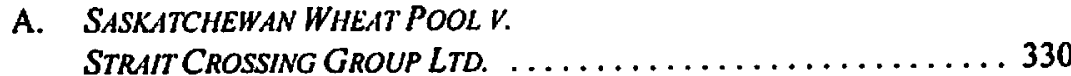

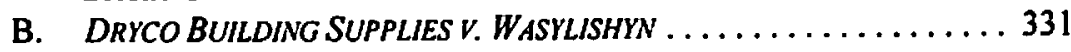

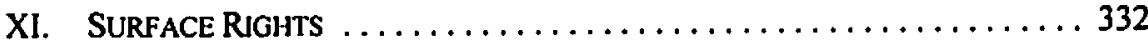

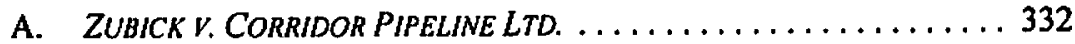

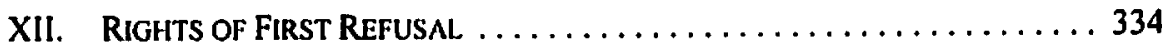

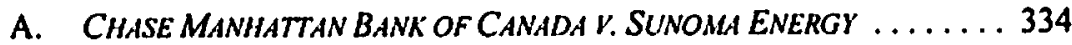

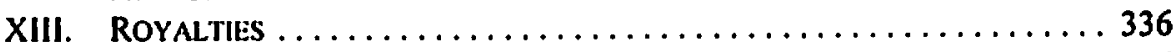

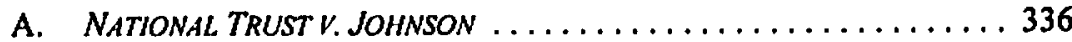



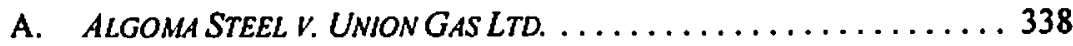

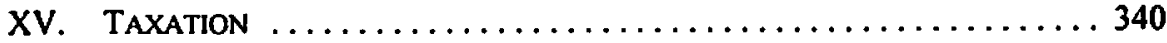

A. CNG PRODUCING V. ALBERTA

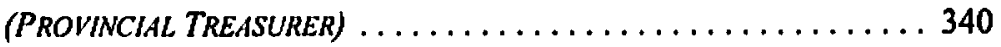

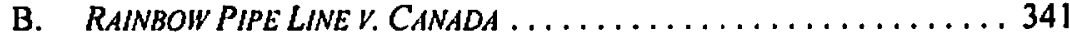

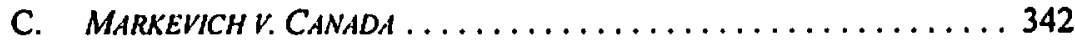



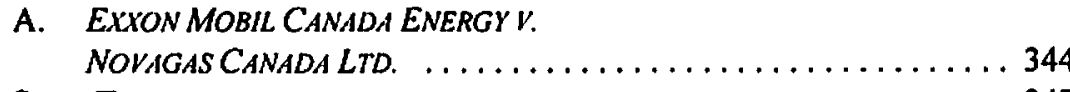

XVII. SPLIT TITLE $\ldots \ldots \ldots \ldots \ldots \ldots \ldots \ldots \ldots \ldots \ldots \ldots \ldots \ldots \ldots \ldots \ldots \ldots$

A. ANDERSON V. AMOCO CANADA OLL AND GAS . . . . . . . . . . 347

XVIII. CONFLICTS OF INTEREST . . . . . . . . . . . . . . . . . . . . 349

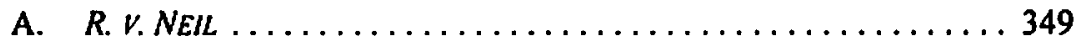

XIX. TORTIOUS INTERFERENCE WITH CONTRACTUAL RELATIONS $\ldots \ldots \ldots \ldots 353$

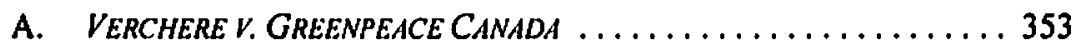

\section{ADMINISTRATIVE LAW}

A. PARAMOUNT RESOURCES LTD. V. ALBERTA (ENERGY AND UTILITIES BOARD) AND DEVON CANADA V. ALBERTA (ENERGY AND UTILITIES BOARD)

\section{BACKGROUND}

In matters before tribunals that employ their own in-house expert staff, counsel have long been uneasy about the relationship between a panel hearing a particular dispute and that panel's staff. These cases illustrate that concern and begin to probe into the depths of this important and delicate issue. 


\section{FACTS}

During the course of a lengthy and complex hearing before the Alberta Energy and Utilities Board (AEUB), two issues concerning the practice of the AEUB and its members and staff were brought before the Alberta Court of Appeal on applications for leave to appeal.'

The first application was made by Paramount Resources Ltd. (Paramount) in reference to a paper scheduled to be presented by a senior member of AEUB staff at an industry conference that was held in Calgary during the course of the hearing. The topic of the paper dealt with issues that were before the AEUB in the hearing. The fact of the proposed presentation was brought to the AEUB's attention and the AEUB issued a decision on the matter stating that no member of the AEUB panel had read the paper, nor had there been any communication had between the panel members and the author of the paper. Paramount applied for leave to appeal the AEUB's decision, stating that the AEUB erred in law or jurisdiction by concluding that there was no reasonable apprehension of bias, no violation of the principles of natural justice, nor any taint to the proceedings before the AEUB. Counsel for the AEUB argued on the application for leave to appeal that no direct or indirect communication had occurred between the author of the paper and the AEUB panel or AEUB staff and thus there was no impairment of the AEUB's ability to consider the matters before it in the hearing impartially and fairly. ${ }^{2}$

The second application was made by Devon Canada (Devon) on the subject of the permissible scope of communication between AEUB staff and the sitting AEUB panel. ${ }^{3}$ During the hearing, the AEUB had issued a letter stating that members of the AEUB panel and AEUB staff would be conducting examinations of actual core samples of the geological zones at issue in the hearing. Devon objected to any communication between staff and panel members arising in connection with such examinations, as they were not conducted within the presence of hearing participants. This objection led to a broader discussion and submissions to the AEUB by the hearing participants regarding the extent of the allowable communication between the members of the AEUB panel and the expert staff of the AEUB. In a decision of the AEUB dated 30 April 2002, the AEUB concluded that "it was permitted to discuss the evidence and arguments with its staff in order to assist it in arriving at its own conclusions."

Devon sought leave to appeal the AEUB's finding, citing a denial of the principles of natural justice and, in particular, the principle of audi alteram partem. Counsel for the AEUB presented evidence as to the nature of the legislative provisions governing the AEUB's use of its staff. They argued that the principles of natural justice were met with respect to the core examination, as the hearing participants were advised of the core in which the AEUB was

Paramoum Resources Lid. v. Alberta (Energy and Utilities Board). Decision of the Alberta Energy and Utilities Board, 21 June 2002: Appeal No. 02.0237 AC [02-0237 AC]; Devon Canada v. Alberia (Energy and Utilities Board) (2003), 3 Admin. L.R. (4ih) 154 (Alta. C.A.) [Devon].

02-0237 AC, ibid.

Decision of the Alberta Energy and Utilities Board, 30 April 2002: Appeal No. 02-0174 AC [02-0174 $\mathrm{AC}]$.

(29 August 2002), AEUB Memorandum of Argument and Authorities of the Respondent [unpublished]. in ibid. 
interested and were provided an opportunity in which to comment and address the other hearing participants' positions. Both applications for leave to appeal were denied.

\section{DECISION}

Dealing with both applications in one written Reasons for Decision, ${ }^{5}$ McFayden J. found that the Devon application was premature and was more properly brought as an appeal of the final decision of the AEUB, and that the allegation of reasonable apprehension of bias in the Paramount application was not seriously arguable. ${ }^{6}$

\section{B. DR. $Q$ V. College of PhYSiCIANS ANd SURgeons of BRItish Columbia' \\ 1. BACKGROUND}

On 3 April 2003, the Supreme Court of Canada simultaneously issued this decision and Law Society of New Brunswick v. Ryan, ${ }^{8}$ discussed below. These two cases arose from appeals from decisions of administrative tribunals and address the principles involved in determining the appropriate standard of judicial review.

\section{FACTS}

An inquiry committee of the British Columbia College of Physicians and Surgeons (the College) found $\mathrm{Dr}$. $\mathrm{Q}$ to have taken physical and emotional advantage of a patient. This constituted "infamous and unprofessional conduct" and Dr. Q was suspended from the practice of medicine for eighteen months. In making its determination, the College was required to make a finding of credibility and favoured the evidence of the complainant over the contrary evidence of Dr. Q. Upon appeal by Dr. Q, the reviewing judge of the British Columbia Supreme Court set aside the inquiry committee's decision and suspension. The College appealed to the British Columbia Court of Appeal. The Court of Appeal could not reach the conclusion that the reviewing judge was "clearly wrong" and, accordingly, dismissed the appeal. The College then appealed to the Supreme Court of Canada.

\section{DECISION}

In a unanimous decision written by McLachlin C.J.C., the Supreme Court allowed the appeal of the College. The key question before the Supreme Court was whether the reviewing judge ought to have interfered with the findings of credibility made by the inquiry committee. The Supreme Court found that the reviewing judge had correctly assessed her duty. "[T]he reviewing judge's task is not to substitute his or her views of the evidence for those of the tribunal, but to review the decision with the appropriate degree of curial deference."10 However, as the reviewing judge then pursued a wide-ranging review of the evidence,

Devon, supra note 2.

Ibid. at para. 38.

[2003] I S.C.R. 226 [Dr. Q]

[2003] I S.C.R. 247 [Ryan].

Dr. Q, supra note 7 at para. 14.

Ibid. at para. 16. 
ultimately substituting her views on credibility for those of the inquiry committee, the appeal was allowed. The Supreme Court placed particular emphasis on the considerable deference ordinarily to be given by appeal courts on matters of credibility. The reviewing judge also erred by concluding, based upon the existence of a statutory right of appeal, that the usual administrative law principles applicable to judicial review of the decision of a tribunal were not applicable in this case.

Chief Justice McLachlin restricted the analysis of a reviewing judge to a determination of the appropriate standard of review, which in turn is to be resolved by applying the pragmatic and functional approach. Based upon a review of recent cases, McLachlin C.J.C. distilled the analysis down to four contextual factors: (1) the presence or absence of a privative clause or statutory right of appeal; (2) the expertise of the tribunal relative to that of the reviewing court on the issue in question; (3) the purposes of the legislation and the particular provision; and (4) the nature of the question - law, fact, or mixed law and fact. The four factors may overlap and the overall aim is to ascertain the intent of the legislature in establishing the task of the tribunal. Addressing legislative intent, the Court stated, "[a]s a general principle, increased deference is called for where legislation is intended to resolve and balance competing policy objectives or the interests of various constituencies."

The currently recognized standards of review are as set out in Ryan. Applying those standards, the Supreme Court found the reasonableness simpliciter standard to be applicable to $D r . Q$. The reviewing judge effectively applied the wrong standard (that of correctness) by failing to give weight to the purposes of the enabling legislation and the findings of credibility by the inquiry committee. Both of these findings heavily mitigate towards increased deference. Where reasonableness simpliciter is the appropriate standard, "the reviewing judge's role is not to posit alternate interpretations of the evidence; rather it is to determine whether the Committee's interpretation is unreasonable."'2

The Supreme Court also found that the Court of Appeal applied the wrong test. ${ }^{13}$ In conducting appellate review of a decision of a lower court, no deference is due.

\section{COMMENTARY}

Dr. $Q$ is a helpful update in the evolution of Canadian administrative law principles applicable to judicial review of administrative tribunal decisions, but must be read together with the Ryan case. 


\section{LAW SOCIETY OF NEW BRUNSWICK V. RYAN ${ }^{14}$}

\section{BACKGROUND}

As mentioned, the Ryan case is a companion of $D r . Q$, and both cases were handed down together.

\section{FACTS}

A lawyer in New Brunswick in a private law practice was found to have lied to clients over an extended period of years about a lawsuit he had undertaken but did not pursue. Ryan went so far as to forge a judgment of the New Brunswick Court of Appeal, which appeared to be an award of that Court in the clients' favour. Upon his finally abandoning the charade, the clients complained to the Law Society. The Law Society referred the matter to its discipline committee, which found that the lawyer should be disbarred. The lawyer appealed and sought to adduce medical evidence respecting mental disability, due in part to alcohol abuse. The Court of Appeal ordered the case reopened. The discipline committee considered the medical and psychiatric evidence and confirmed its earlier disbarment decision. The Court of Appeal then allowed the respondent lawyer's second appeal and substituted its own sanction (an indefinite suspension) instead of disbarment. The rationale for interference by the Court was recent decisions of other appellate courts concerning professional discipline bodies. These decisions moved the standard of "reasonableness" closer to correctness than to patent unreasonableness, particularly in circumstances where a harsh sanction, such as disbarment, might be imposed. In other words, the Court of Appeal saw the varying standards of judicial review of an administrative decision as a "sliding-scale."

\section{DECISION}

In a unanimous decision written by lacobucci J., the Supreme Court allowed the appeal of the Law Society. Justice lacobucci concluded that there exist only three standards of judicial review. In ascending order of deference, these are: correctness, reasonableness and patent unreasonableness. A reviewing court must not interfere with an administrative tribunal's decision unless the appropriate threshold is attained. The Court further found that the reasonableness simpliciter standard does not vary according to the circumstances.

On any appeal from a decision of an administrative tribunal, the appeal court must apply the pragmatic and functional approach adopted in $D r$. $Q$. The pragmatic and functional approach requires assessment of the four criteria set out in $D r . Q$. No one criterion is determinative. For example, in this case a statutory right of appeal may indicate that less deference is due to the lower tribunal. However, the expertise of this particular tribunal, which may be derived from specialized knowledge or from experience or skill in determining particular issues, as well as the legislative scheme pursuant to which the tribunal is established, might suggest a higher degree of deference. The decision identifies the circumstances where the three varying standards of judicial review may be applied and the consequences of their application. Of the patently unreasonable standard, lacobucci J. wrote 
"A decision that is patently unreasonable is so flawed that no amount of curial deference can justify letting it stand."15

Applying the pragmatic and functional approach, the Supreme Court concluded that the appropriate standard in Ryan was reasonableness simpliciter. Consequently, the Court of Appeal should only have substituted its own view of the "correct" sanction if the decision of the Law Society discipline committee was shown to be unreasonable. In applying the reasonableness simpliciter standard, if the reasons given support the decision, then the appellate court must not interfere, even if it would have come to a different conclusion. Justice lacobucci put it succinctly: "Judicial review of administrative action on a standard of reasonableness involves deferential self-discipline."16

\section{COMMENTARY}

This case reins in the recent tendency of appeal courts to move away from deference for the decisions of expert tribunals. Dr. $Q$ and Ryan address different aspects of the issue. Taken together, they provide a blueprint for the analysis which henceforth must be undertaken by appellate courts in such appeals, regardless of the standard of review ultimately determined to be applicable.

\section{ALBERTA (ENERGY RESOURCES CONSERVATION BOARD) V. SARG OILS LTD. ${ }^{17}$}

\section{BACKGROUND}

This case raises the question of whether the Energy Resources Conservation Board (ERCB; now the AEUB) can recover well abandonment costs from a well licensee, Sarg Oils Ltd. (Sarg), where Sarg arranged for the delivery of duly-executed well licence transfers to the ERCB , but the ERCB did not process them on a timely basis. This case is somewhat dated insofar as it relates to the faimess of the ERCB's procedures, since it addresses those procedures as they applied to well licence transfers in the months leading up to the ERCB's information letter IL 89-22 ${ }^{18}$ and the ERCB's orphan well and well licence transfer policy. The case is nevertheless significant as a reminder of the importance both of completing well licence transfers and of solicitors applying appropriate trust conditions when conveying a well.

\section{FACTS}

Sarg was the licensee of fifteen wells which, in 1988, it agreed to sell to Sundial Oil \& Gas Ltd. (Sundial). The agreement between Sarg and Sundial included an indemnity by Sundial to the date of the conveyance. On the instructions of Sarg's principal, Sarg's lawyer prepared the necessary documents (including transfers of the well licences) and sent them to Sundial's lawyer on certain trust conditions. 
While the transfers were being examined by ERCB staff, the agreement between Sarg and Sundial was apparently completed with Sundial taking over operation of the wells and the purchase moneys being released to Sarg. Uitimately, because of deficiencies in Sundial's applications for transfer of the well licences, the transfers of the well licences were not approved by the ERCB.

In July/August 1993, the ERCB carried out the abandonment of the wells because Sundial had failed to do so. The ERCB invoiced Sarg for the costs. Sarg refused to pay. In October 1994, the ERCB issued a statement of claim against Sarg for the abandonment costs. Sarg issued a third party notice against its lawyer, claiming professional negligence and against Sundial's lawyers claiming that they had breached the trust conditions imposed on them.

The trial judge rejected the ERCB's argument that Sarg's defence to the ERCB's claim for the abandonment costs was a collateral attack on the validity of the orders underlying the ERCB's claim. He held that the ERCB should not be permitted to enforce a statutory debt that arose when the ERCB's failure to process the well licence transfers from Sarg to Sundial in a timely manner was found not to meet the test of procedural fairness.

\section{DECISION}

The Alberta Court of Appeal reversed the trial judge's decision on the substantive issues set forth below.

\section{a. Collateral Attack}

The legislature intended that the ERCB, rather than the courts, deal with the matters at issue here. The trial judge was held to have erred in permitting a collateral attack on the ERCB's decisions and orders. His chief concern - about the fairness of the ERCB's procedures - could and should have been argued before the ERCB itself and possibly later before the Court of Appeal. However, if the fairness arguments were well-founded, the result would have been a rehearing before the ERCB, not the substantive remedy provided by the trial judge. His decision undermined the integrity of the administrative system and placed the decision making outside the control of the body intended by the legislature to exercise it.

\section{b. Other Grounds of Appeal}

The ERCB also argued that the trial judge was wrong to find that it had treated Sarg unfairly and that the doctrine of equitable estoppel barred the ERCB's claim. Given the Court's conclusion on collateral attack, it was unnecessary to consider these arguments.

\section{c. Amount of the ERCB's Claim}

The broad language of ss. 92(2) and 95(4) of the Oil and Gas Conservation Act ${ }^{19}$ made it clear that the ERCB had a very wide discretion to determine abandonment costs. That 
language does not limit such costs to the ERCB's out-of-pocket expenses. Therefore, the ERCB's claim should not have been reduced.

In the second appeal, heard at the same time as the first, Sarg appealed the trial judge's refusal to grant its claim for the statutory debt against its own lawyer or Sundial's lawyers. The Court, however, was not persuaded that the trial judge was wrong to dismiss these third party claims.

Regarding the allegations of liability of Sundial's lawyers, the Court held that the trial judge's analysis was consistent with the wording of the trust condition itself and the evidence in this case, including the evidence of the experts. The trust condition did not say that those lawyers were personally responsible for registering the documents at the ERCB (rather than having their client submit the documents), nor did they treat receipt of the filed copies as a precondition to closing. Moreover, shortly after the executed (rather than filed) documents were received by Sarg's lawyer, he wrote to Sundial's lawyers stating that he was releasing the sale proceeds to Sarg and looked forward "to receiving duplicate filed documents." ${ }^{20}$ It was apparent that the parties themselves treated provision of filed documents as a postclosing matter. This ground of Sarg's appeal, therefore, was held to be without merit.

In the result, the appeal of the ERCB was allowed in its entirety. Sarg's cross-appeal and appeal on third party liability were both dismissed.

\section{COMMENTARY}

A number of important lessons arise from this case. First, challenging decisions of the ERCB, almost without exception, will require a direct attack by requesting a review of the decision by the ERCB or by seeking leave to appeal to the Court of Appeal. A collateral attack on the decision, by simply not complying with the direction of the ERCB and later arguing that it was made without jurisdiction or was otherwise unlawful, is not likely to succeed.

From a practice point of view, legal counsel need to always remember that consideration paid for the acquisition of an existing well comprises not only the monetary or other immediate consideration, but also the consideration arising from the purchaser assuming liability for abandonment and reclamation costs. Consequently, if counsel for a vendor is to ensure full payment of all consideration for the purchase of a well, appropriate trust conditions need to be imposed that prevent a purchaser from taking possession of the well, unless and until a transfer of the well licence has been effected. From the purchaser's solicitor's point of view, he should require absolute clarity as to what responsibility he or his firm may have for the completion of the registration of well licence transfers with the ERCB (now the AEUB). 


\section{BUILDERS' LIENS}

\section{A. PTI GROUP V. ANG GATHERING \& PROCESSING LTD. (C.O.B. TRANSCANADA MIDSTREAM) ${ }^{21}$}

\section{BACKGROUND}

In the petroleum and natural gas industry, there is always an issue about the applicability of builders' lien legislation concerning the provision of so-called secondary services not directly performed on the improvements, particularly when those services are not performed on the lands that are actually to be liened. This issue is particularly common with regard to the construction of pipelines, processing plants and the like.

This appeal concerned the validity of a builders' lien filed against a gas pipeline right-ofway by a sub-contractor who furnished catering services, sleeping trailers and kitchen facilities to accommodate the work force of the contractor, Serval Corporation and Serval Enterprises Inc. (collectively Serval). The services in question were provided by PTI Group Inc. (PTI), which subsequently registered a builders' lien under the Builders' Lien Act $^{22}$ after Serval failed to pay.

\section{FACTS}

ANG Gathering \& Processing Ltd. (ANG) entered into a contract with Serval whereby Serval was to construct a 48 kilometre section of a gas pipeline. It was anticipated that Serval would provide its workforce with lodging and catering services, given the express requirement in the contract with ANG that Serval provide "all services, labour, supervision, travel, subsistence, equipment, fuel, tools, goods and material required to fully perform the work." ${ }^{23}$ Although the contract did not specify the precise manner in which subsistence would be provided, it was open to Serval, and understood by ANG, that Serval would be utilizing a camp caterer for this project. PTI was engaged by Serval to furnish lodging, meal services, washroom facilities, recreational facilities, laundry and all trailers and equipment required for those purposes. Meals were prepared at the camp and breakfast and dinner were served there. Bag lunches were prepared for the work crews who took them to the work site.

The pipeline right-of-way granted to ANG was 18 metres wide. It was agreed that the subsistence camp was not to be located directly on the right-of-way. Indeed, given the width of the right-of-way and the nature of the work to be performed, one can reasonably infer that it would have been difficult, if not impossible, to erect the camp on the right-of-way. Accordingly, the camp was located approximately 115 metres from the right-of-way on a quarter section through which the right-of-way passed. The builders' lien filed against the pipeline right-of-way was for the amount outstanding to PTI of $\$ 511,568.75$.

An application was brought before a Master in Chambers to determine the validity of the lien. The Master declared the lien to be invalid upon holding that: 
- $\quad$ PTI provided services to Serval;

- $\quad$ such services were not provided or performed on the lands liened; and

- $\quad$ services, such as those provided by PTI, must be provided directly on the lands liened in order to maintain a valid builders' lien. ${ }^{24}$

An appeal to a judge in chambers was dismissed.

\section{DECISION}

The decision of the Court in Hett v. Samoth Realty Projects Ltd., ${ }^{25}$ endorsed by the Court of Appeal in Alberta Gas Ethylene Lid. $v$. Noyle, ${ }^{26}$ established that services need not be physically performed upon the improvement to fall within the meaning of the Builders Lien Act. They must, however, be "directly related to the process of construction."27

The respondents maintained that for such off-site services to be lienable, however, a second test must be met - The services must be an integral and necessary part of the actual physical construction of the project. This test was said to derive from the language employed by Lieberman J.A. in his assessment of the services of an architect in Hett.

In fact, although Lieberman J.A. did characterize the services of an architect as an integral and necessary part of the actual physical construction of the project, he did so to better explain how those services were "directly related to the process of construction." 28 The choice of language was an attempt to describe the direct nexus with the improvement that the services of an architect enjoy along with other services similarly related to the construction process. It was an attempt to distinguish, on a principled basis, between primary services which have the attributes of proximity and those which are relatively remote and sometimes described as secondary. Mere contribution to the total project will not entitle the person who performed the work to file a lien. Examples offered by Lieberman J.A. as being too remote were the services of a lawyer, accountant, sociologist or statistician. It was not, as counsel suggested, the cerebral nature of the contribution to the improvement that governed; rather, it was the degree of proximate connection to the process of construction that must be evaluated.

The availability of lien rights for secondary services must be subject to some limit that will largely be determined by the factual matrix of each case.

\section{COMMENTARY}

In this case, the Court has prescribed four enquiries to be examined when determining whether what appear to be secondary services conducted off-site qualify for builders' lien protection: 
whether the contractors, sub-contractors and owners contemplated that the services provided were necessary to expedite the construction of the improvement; whether the off-site services could have been provided on the site; whether the improvement could have been carried out absent such off-site services; and

whether, in all of the circumstances, the off-site services were so essential to the construction of the improvement and so directly connected with the improvement that it can be said that the services in question were "primary" in nature.

Thus, although the determination is largely fact-driven, the foregoing four enquiries provide a road map for the determination. This is very helpful in light of the predilection of subcontractors to approach counsel about the availability of lien rights in the afternoon of the 45 th day (or 90th day, as the case may be) after provision of the services.

The facts of this case were found to meet these tests, the appeal was allowed, and the lien was declared valid.

\section{B. TIME SEISMIC EXCHANGE LTD. $V$. NORTHERN MOUNTAIN HELICOPTERS ${ }^{29}$}

\section{BACKGROUND}

This case aroses from the non-payment of a subcontractor by a party that was accumulating speculative seismic data. The work was done without direction from, and perhaps even without the knowledge of, the holder of the mineral interest. Those unique facts may render this decision somewhat specific to its facts. Nevertheless, the case is important because it grapples with three significant issues of interest to the oil and gas industry. The first has to do with whether the accumulation of seismic data constitutes an "improvement" for the purpose of the current Builders' Lien Act. ${ }^{30}$ The second illustrates the application of the four part enquiry prescribed in PTI Group ${ }^{31}$ for the determination of whether secondary services are directly related to the carrying out of an improvement. The third deals with whether a lien can be filed against the estate or interest of a party that is not contractually connected, directly or indirectly, to the party carrying out the work.

In this case, Northern Mountain Helicopter Inc. (Northem Mountain) brought an appeal before Moshansky J. in the Alberta Court of Queen's Bench after the Master dismissed its application for a declaration that its builders' lien against Time Seismic Exchange Ltd. (Time Seismic) was valid and enforceable.

\section{FACTS}

Time Seismic operated a 3D seismic imaging service for the discovery of underground mineral deposits. It created speculative seismic data and then licensed it to oil and gas exploration and production companies through its affiliate, Veritas DGC Land Inc. Time 
Seismic contracted with Eagle Surveys 2000 Inc. (Eagle Surveys) to provide transportation for its work crews to carry out surface cutting of seismic lines for its seismic program in remote locations in northern Alberta. Eagle Surveys, in turn, contracted with Northern Mountain to provide helicopter transportation for the work crews to the work sites.

Time Seismic paid Eagle Surveys the full amount of its contract, but Eagle Surveys did not pay Northern Mountain. Northern Mountain then registered a lien upon the interest in Crown minerals, pursuant to the Lien Act, against the land upon which the survey was done.

The Master had determined that the work done by Northern Mountain was not work in relation to an improvement of the mineral rights and declared the lien invalid.

\section{DECISION}

a. Is the Seismic Program an Improvement?

Time Seismic, and those hired by its affiliate or subcontractors, did not physically construct anything on the land, or anywhere else, in conducting the seismic program. They simply collected data about the subsurface minerals and attempted to sell that information to the holders of the mineral rights or others. These actions alone were held to not meet the definition of "improvement" in the Lien Act.

Section 6(2) of the Lien Act provided that work done "preparatory to" the recovery of minerals did not create an additional definition of "improvement" in the mineral recovery context that included preparatory work. Accordingly, Moshansky J. held that the exhaustive definition of "improvement" would be stretched beyond its reasonable confines if it were to be interpreted to include any act that enhances the value of the land.

Time Seismic did not construct, erect, build, place, dig or drill anything on or in the land. In these circumstances, the respondent's seismic program was more akin to the services provided by a solicitor or accountant and, while it might have increased the value of the land, it did not constitute an improvement for the purposes of the Lien Act.

b. If the Seismic Program is an Improvement, does Transportation of Workers to the Work Site Constitute Work "in Respect of" the Improvement?

In the event that that it was wrong in holding that the seismic program was not an improvement, the Court addressed further issues raised by the appellant's argument. The transportation of workers to a remote work site was held to be "directly related" to the process of carrying out the improvement in accordance with the criteria set out in PTI Group. Given the remote location of the camp. Time Seismic must have contemplated that transportation services for the workers would be required. The Court disagreed with the Saskatchewan Court of Queen's Bench in Points North Freight Forwarding v. Coates Drilling Ltd. (Trustees of $)^{32}$ that transportation to the work site, even in remote areas, is the responsibility of the employee. The transportation of the workers to the work site fell within 
the ambit of work "in respect of" an improvement within the tests set forth by the Alberta Court of Appeal in PTI Group.

c. If the Seismic Program is an "Improvement" and Transportation of Workers to the Work Site is Considered "Work in Respect of the Improvement," was the Work Done for an "Owner, Contractor or Sub-contractor"?

The Court held that the work was not done for an owner or contractor. With regard to subcontractors, the Court held that the wording of the Lien Act implied that the intention of the Lien $A C t$ is that a contractor or subcontractor must be able to trace its contract back to the owner.

Further support for this contention is found in the definition of "owner"33 and in the general purpose of the Lien Act. Granting a builders' lien is an extraordinary remedy that allows the worker to recoup his wages from the person whom his efforts were intended to, and in fact did, benefit rather than from the person who hired him to do the work. This would seem inequitable were it not for the fact that an owner, for the purposes of the Lien Act, is specifically defined as the person at whose request the work was done.

Eagle Surveys did not contract with a contractor or a subcontractor and, consequently, cannot trace its contract back to the owner of the land. Accordingly, Eagle Surveys is not a subcontractor for the purposes of the Lien Act.

\section{COMMENTARY}

This case could have been more expeditiously dispensed with on the basis that parties collecting so-called "spec data," without any contractual connection to the owner or holder of the mineral rights, do not have, nor do its subcontractors have, any lien rights under the Lien Act. That principle, however, has been relegated to an obiter dictum in this case. A query is whether the gathering of seismic data may qualify as an "improvement" under the Lien Act if it were conducted at the direction of the holder of the mineral rights, particularly if the seismic program was an integral precursor to a well drilling program? The Court's decision that such work does not constitute an improvement may tum on the specific facts of this case. The availability of lien rights to the transportation subcontractor, although also obiter in this case, is a good example of the application of the four-part enquiry process prescribed in PTI Group. 


\section{Conflict of Laws}

\section{A. HERMAN V. ALBERTA (PUBLIC TRUSTEE) ${ }^{34}$}

\section{BACKGROUND}

As oil and gas exploration and production work increases in the north, solicitors must always remain vigilant to the complexities that can arise from multi-jurisdictional activities.

\section{FACTS}

An aircraft chartered to fly from Fort McMurray, Alberta to La Loche, Saskatchewan crashed in Saskatchewan and two persons on board were killed. Actions for damages were brought and an application was made to determine the proper law governing the actions.

\section{DECISION}

Although Saskatchewan law was the proper substantive law for a tort action, since Saskatchewan was the place of injury, the Court found that an action based in contract would be governed by Alberta law since: (1) the charter contract was made in Alberta; (2) the subject matter of the contract was neutral, as it involved both provinces; (3) substantially all of the performance of the contract took place in Alberta; (4) the location of the breach of contract was not a circumstance existing at the time that the contract was made and was thus irrelevant; and (5) the head office of a party may or may not be determinative, but all of the parties, save one, were resident or incorporated and registered in Alberta. The decision also dealt with the question of which crash victims were parties to the contract, directly and by agency and which, if any, could qualify for additional heads of damages under Alberta's Fatal Accidents $\mathrm{Act}^{35}$ that were not available in tort actions under Saskatchewan law.

\section{COMMENTARY}

Care should be taken to always include selection of the governing law and a selection of forum wherever possible in the drafting of an agreement.

\section{CONTRACTS}

\section{A. AMJ CAMPBELL V. KORD PRODUCTS ${ }^{36}$ \\ 1. BACKGROUND}

This is a "million dollar comma" case that reminds legal draftsmen not only of the great care that must be taken in drafting and revising agreements, but also in having the client very carefully review every draft of the document as it evolves toward an execution copy. 


\section{FACTS}

The parties to the action were involved in the drafting of an agreement dealing with the sale of assets of a subsidiary of the plaintiff, AMJ Campbell (the Vendor) to the defendant, Kord Products (the Purchaser). The agreement went through many revisions. Near the end of the negotiations, the Purchaser's lawyer requested several changes, including the addition of a comma to the definition of "Average Selling Price." The Vendor's lawyer obliged and the definition was changed from "net of taxes, freight rebates and discounts" to "net of taxes, freight, rebates and discounts." This definition proved to be central to the valuation of certain inventory that formed the major part of the assets being sold, resulting in a discrepancy of $\$ 759,000$ in the final price. The Vendor applied for rectification of the purchase and sale agreement to delete the comma placed between "freight" and "rebates" in the subject definition.

\section{DECISION}

In declining to exercise its discretion to allow rectification, the Court found that the Vendor either "knew" of the comma or could not be allowed to take the position that it was not aware of it. First, the Court held that the Vendor's solicitors had agreed to the insertion of the comma and the solicitors were, at all times, acting as agents for the Vendor: "The law is clear that knowledge of the agent is deemed to be knowledge of the principal." ${ }^{37}$ Second, the Court found that the Vendor's Chief Executive Officer, who had been reviewing the agreement, did not read the black-lines carefully. Attention had been drawn to the subject definition for other reasons, but he had missed the addition of the comma.

The Court went on to cite the Supreme Court in Marvco Colour Research Ltd. v. Harris ${ }^{38}$ for the proposition that a party who executes a document without taking the trouble to read it is liable and cannot argue that he or she misunderstood the contents as against a party who acted in good faith in relying on that same document. Regarding this good faith reliance, the Court found that the Purchaser had acted ethically in adding the comma between "freight" and "rebates" in the definition. There was no evidence of improper conduct on the part of the Purchaser that would suggest that the equities should favour the Vendor in this case. Further, notwithstanding what might have been the contrary intention of the parties with respect to this definition, the agreement contained an "entire agreement" clause.

\section{COMMENTARY}

This case illustrates a lawyer's worst nightmare where something that seems so minor, such as a comma, can make a world of difference to the economic result of the intended agreement. This case is also significant in reminding us once again of the very limited scope of the rectification remedy. It is applied only in very rare and unusual circumstances and is not a remedy that is ordinarily useful to repair a drafting error or a misunderstanding between the legal draftsperson and his or her client. 


\section{B. CANADIAN BRoadcasting Corp. PEnsion PLAN (TRUstee of) V. BF REALTY HOLDINGS LTD. ${ }^{39}$}

\section{BACKGROUND}

This case is significant because it adds to the limited amount of reported Canadian case law interpreting the phrase "all or substantially all of the assets" of a business.

\section{FACTS}

The appellant plaintiffs were holders of debentures of BCE Development Corp. (BCE), the predecessor to BF Realty Holdings Ltd. The trust indenture governing the debentures contained a provision that prohibited BCE from entering into any transaction that transferred "all or substantially all" of its assets to another corporation, unless that corporation assumed the obligation to pay the debt owed under the debentures. A reorganization was completed by $B C E$ in which $B C E$ transferred assets to its various subsidiaries and secured a debt by way of guarantee and a pledge of shares held by BCE in a valuable subsidiary, all without reference to the trust indenture. Due to BCE's financial difficulties, those pledged shares were foreclosed upon.

The debenture holders argued that the combination of the reorganization and granting of security triggered the provisions in the trust indenture because they resulted in "all or substantially all" of the assets of BCE becoming the property of another corporation. Thus, it was argued that the obligation to pay the debt owed under the debentures should have been assumed by those corporations receiving the assets. The trial judge found that there had not been a movement of assets that triggered the provisions of the trust indenture and the debenture-holders appealed.

\section{DECISION}

In determining whether or not "all or substantially all" of BCE's undertakings, property and assets were transferred in the subject transaction, the Ontario Court of Appeal reviewed the limited number of Canadian decisions dealing with the interpretation of "substantially all" in the context of similar wording in corporate statutes. Noting the importance of considering both the qualitative and quantitative aspects of a transaction, the Court stated that "one interpretative test, having both quantitative and qualitative aspects, governs." ${ }^{40}$ Describing these separate aspects, the Court stated that:

The quantitative aspect of the interpretative test is formulaic, requiring a comparison of the proportion, or relative value, of the transferred property to the total propenty of the iransferor ...

In contrast, a qualitative analysis seeks to determine the nature of a transferor's core business aclivitics. and the property involved in carrying out such activities. The purpose of the inquiry is to assess whether the 
transferred property is integral to the transferor's traditional business, such that its disposition or transfer strikes at the heart of the transferor's existence and primary corporate purpose. ${ }^{41}$

In considering the quantitative factors, the Court noted that the trial judge had found that BCE was the apex of a pyramid of subsidiary corporations which, in turn, had their own subsidiaries. The reorganization had involved transfers among these various subsidiaries but, at most, had involved a transfer of only 18 percent of BCE's directly-held assets.

With respect to the qualitative portion of the analysis, the appellants argued that the effect of the reorganization was to make BCE a passive holding company for a single asset, namely the shares of its valuable subsidiary. In dismissing this argument, the Court again cited the trial judge's finding that $\mathrm{BCE}$ was the apex of a complex corporate structure and further cited the trial judge's finding that BCE was a holding company with its principal properties held by subsidiaries both before and after the reorganization. The Court noted that the reorganization did not involve a divestiture by BCE of its shares in its subsidiaries, nor was a new company created to which assets were diverted. BCE's character and corporate purpose were not altered by the subject transactions.

\section{COMMENTARY}

Oil and gas lawyers have spent a lot of time arguing about the meaning of the phrase "all or substantially all of the assets" of a business in the context of one of the exclusions to the right of first refusal contained in art. XXIV of the Canadian Association of Petroleum Landmen (CAPL) Standard Forms of Operating Procedure..$^{42}$ It is useful to add this careful analysis by the Ontario Court of Appeal to the bank of authority previously available to assist in that assessment in future cases.

\section{SOLWAY V. DAVIS MOVING \& STORAGE (C.O.B. KENNEDY MOVING SYSTEMS) ${ }^{43}$}

\section{BACKGROUND}

Exclusionary clauses of one form or another that attempt to exclude, or at least limit, damages or other claims that can be made, are an ever more important aspect of the legal work for clients in the petroleum and natural gas industry in Canada today. This case illustrates the application of current judicial thinking on that subject.

\section{FACTS}

The plaintiffs hired the defendant mover to move their household possessions based on their previous experience with the defendant. The plaintiffs' possessions included many artifacts, antiques and items of sentimental value, a fact of which the defendant mover was aware, both having seen the items and having made comments to that effect on previous

13 (2002), 62 O.R. (3d) 522 (C.A.); application for leave to appeal to S.C.C. dismissed without reasons, [2003] S.C.C.A. No. 57. 
occasions. The plaintiffs were told that the trailer containing their goods would be located overnight in the defendant's fenced and locked parking lot. Before completing the move, however, the trailer was instead left overnight on a public street outside the lot to allow for snow-plowing of the lot. The trailer, though locked, was stolen from the street and none of the goods were recovered. The plaintiffs sought the replacement cost of their goods. The defendant mover attempted to rely on a limitation of liability clause in the bill of lading and Regulation 1088 under the Truck Transportation $\mathrm{Act},{ }^{44}$ which would limit its liability to $\$ 0.60$ per pound, for a total of $\$ 7,089.60$.

The trial judge found that the plaintiffs had not been advised that their goods would be left unattended and parked on a public street and, further, that the defendant mover had given false assurances that the goods would be secured. Thus, the defendant had induced the plaintiffs to agree to the limitation clause. In granting relief to the plaintiffs, the trial judge considered the decision of the Supreme Court of Canada in Hunter Engineering v. Syncrude Canada L Ld ${ }^{45}$ in determining that this was an appropriate circumstance for a Court to choose to interfere with a potentially unfair contract. The trial judge also awarded damages in favour of two corporations owned by the plaintiffs for loss of income due to the time the plaintiffs had spent dealing with the issues arising from the theft. The defendant mover appealed both aspects of the decision.

\section{DECISION}

In discussing the trial judge's reliance on the reasoning in Hunter Engineering regarding the enforcement of exclusion or limitation of liability clauses, the majority of the Ontario Court of Appeal made reference to its own reasons in Fraser Jewellers (1982) Lid. $v$. Dominion Electric Protection, ${ }^{\text {t6 }}$ which attempted to reconcile the concepts of fundamental breach and unconscionability as they had been put forth by different judges of the Supreme Court in Hunter Engineering. In Fraser Jewellers, the Court had noted that the difference in practice between application of the alternative tests cited in Hunter Engineering, that is, whether the clause was "unfair" or "unconscionable," was "unlikely to be large." ${ }^{47}$ In a similar manner, the Court in this instance concluded that:

[1]he trial judge appears to have equated the words, "unconscionable" and "unreasonable" as these terms were discussed in Hunter Engineering. In our view, on the facts as found by the trial judge, to limit the loss of the plaintifrs to $\$ 7,089.60$ would, in the words of Dickson C.J.C. be "unconscionable," or in tle words of Wilson

J. be "unfair or unreasonable." This is one of those cases where relief should be granled. ${ }^{48}$

However, although the Court of Appeal dismissed the defendant's appeal on the replacement cost of the goods stolen, the Court reversed the trial judge's award of damages to the plaintiffs' corporations, finding that there was no evidence that the plaintiffs had spent any money replacing their services to the corporations. 
Justice Carthy, in his dissent, disagreed with the trial judge's reasons if on no other account, for reliance on evidence that the consigners were given assurance that their goods would be secure. That assurance must be implicit in every contract for carriage of goods and cannot weaken a limitation of liability clause that contemplates claims where security breaks down and a loss occurs. Justice Carthy also disagreed with the trial judge's interpretation of Hunter Engineering and the consequences of a fundamental breach. He stated that even in cases of a fundamental breach, there are policy concerns that justify the enforcements of an exclusionary clause born in legislation, such as the Truck Transportation Act.

\section{COMMENTARY}

Notwithstanding the inclination of the Ontario Court of Appeal in this case and in Fraser Jewellers to characterize the difference between an exclusionary clause that is "unfair" and one that is "unconscionable" as "unlikely to be large," it would appear that those are two very different tests. Until there is clarification by the Supreme Court of the appropriate tests arising from Hunter Engineering, there is likely to be continued uncertainty as to the applicable principle.

\section{Depar management Ltd. v. Piute Petroleums Ltd.49}

\section{BACKGROUND}

As is often the case today with the constant turnover of oil and gas properties and companies, many transactions far outlive those that initially put them together. This case illustrates the danger of inadequately and informally, documenting arrangements that are made.

\section{FACTS}

The plaintiff claimed for amounts due and owing as a result of alleged improper charges levied by the defendant against the plaintiff in respect of an oil well owned jointly by the partics. The plaintiff alleged that the defendant, while operating a well belonging to both parties, charged the plaintiff for processing and treatment costs, contrary to an agreement made between them approximately thirty-five years earlier.

In 1965 and 1966, the defendant had drilled four wells in the Wainwright area of Alberta. One such well, described as "2B2," was found to be a gas well and was capped for lack of a market. Another of the wells drilled, "3B2," was dry. In 1966, the ERCB required the defendant to inject water into the subject formation to maintain pressure if it wished to continue operating any wells in the area. The plaintiff believed that 2B2 had the potential to become an oil well and so proposed to the defendant that the plaintiff pay for the cost of converting $3 \mathrm{~B} 2$ into an injector well, in turn receiving a half interest in 2B2. That proposal was evidenced by a letter agreement between the parties dated 14 September 1966. The agreement provided that operating costs would be apportioned directly to the appropriate well and, if 2B2 became an oil well, it would be assessed on the producing oil well count 
basis for its area share of the cost of water injection and pressure maintenance. There was no mention of how the parties would share the cost of processing and treating any emulsion that would be produced from the well.

3B2 was converted into a water injection well at a cost of approximately $\$ 15,000$ to the plaintiff, and the plaintiff was assigned a 50 percent interest in 2B2. Within two to three years, 2B2 became a producer. However, the Court found that this was brought about not only by converting 3B2 into a water injection well, but also by illegally carrying out a procedure known as "blowing down" $2 \mathrm{~B} 2$.

Shortly after 2B2 became an oil producer, the defendant paid for a battery facility to be built on the Wainwright lands, which the plaintiff designed, built and operated. Once built, all of the production from 2B2 was processed and treated on-site. From at least 1970 until 1977 , all of the costs related to the battery were divided equally among the producing wells in the area. It was the plaintiff's evidence that this agreement had been made on a verbal basis after the battery had been built. However, no document existed in support of such an agreement, other than the monthly operating statements sent by the plaintiff to the defendant.

By 1972, 2B2 was the largest producer of oil in all of the defendant's operations, accounting for some 30-50 percent of the defendant's total production until at least 1977. In 1974 , the principal of the plaintiff $(\mathrm{F})$ and the principals of the defendant began to falsify the defendant's reporting documents to the ERCB in order to reduce the amount of royalties that the defendant was obliged to pay under the newly introduced National Energy Policy. Instead of reporting the actual production from each well, $F$ would average the total production among all of the producing wells. This resulted in a substantial reduction of the royalties payable on production from $2 \mathrm{~B} 2$.

This scheme continued until 1980 or so, when the son of one of the defendant's principals (P) took over the defendant company after his father had become mentally incapacitated and the other principal had died. $P$ became aware that the defendant had submitted false reports, and instructed $F$ to go back and prepare proper documentation for submission to the ERCB. F did so and was subsequently charged with fraud. In September of 1982, F's operatorship was terminated by P. In 1983, a trial took place and F was convicted of fraud. However, before sentencing, $F$ moved to the United States.

In 1983, a third party $(\mathrm{H})$ acquired the shares of the defendant. By that time, the battery was processing and treating emulsion from a number of other wells in the area, and the defendant was charging the owners of those wells on a per barrel basis for the amount of emulsion being treated. In February 1985, the defendant began to charge the plaintiff an amount for "processing and treating" based upon the amount of emulsion being treated. The plaintiff objected to being charged directly for its share of processing and treating and, in December 1985, commenced this action. The plaintiff argued that not only was an agreement reached with the defendant (while under the control of the former owners) that the plaintiff was only to be charged for the processing and treating costs on a well count basis, but that this agreement could not be unilaterally changed. The defendant counterclaimed, stating that the plaintiff wrongfully and fraudulently misappropriated to itself the processing and treatment costs that it should have been charging to itself from early 1970 to 1985. 


\section{DECISION}

The Court dismissed the plaintiff's claim, finding no intention to contract between the parties with respect to the treatment and processing costs. The Court stated that: "The conduct of the parties in this case indicated no more than a willingness on the part of the defendant to allow the plaintiff to use the battery on a certain basis for so long as it chooses to do so."so

The Court did not accept the plaintiff's evidence that a verbal agreement had been made, noting that any alleged contract must be proven strictly and that the plaintiff had failed to do so. Further, the Court noted that there was no suggestion on the part of the plaintiff that it relied upon, to its detriment, the defendant's conduct in failing to object to how the treating costs were being allocated.

The Court also dismissed the defendant's counterclaim, finding that the defendant, through its principals, was aware or should have been aware that the plaintiff was receiving this benefit. Unfortunately, none of the relevant principals of the defendant still alive was competent to give evidence.

\section{COMMENTARY}

We are all familiar with the equitable principle that one who comes to equity must come with clean hands. In a very practical sense, this case illustrates that a party that has conducted itself in a blatantly unlawful manner has little or no chance of gaining the court's sympathies and, hence, of enforcing any rights through civil litigation. Once a transaction is tainted by unlawful behaviour, the court will be loath to provide its assistance to any of those participating in the misconduct. That is particularly the case when the transaction was not adequately documented. Furthermore, this case also illustrates that where a transaction is not adequately documented, the course of conduct of the parties becomes very persuasive evidence of their intention.

\section{Credtrors' Rights}

\section{A. ENRON CANADA $(R E)^{51}$ \\ l. BACKGROUND}

In Re Blue Range Resource Corporation, ${ }^{\$ 2}$ Fruman J.A. of the Alberta Court of Appeal wrote a lucid and thoroughly reasoned judgment affirming contractual termination and netting out rights of counterparties to derivative contracts where a corporation becomes subject to a protective order under the Companies Creditors' Arrangements $A c t .{ }^{33}$ Enron Canada Corporation (Enron Canada) took the lead in that litigation by enforcing those 
rights. ${ }^{54}$ In this case, the industry was subjected to the spectacle of that same corporation, Enron Canada, seeking the Court's assistance to override those same contractual termination and netting out rights in circumstances where those rights were being triggered by the insolvency of Enron Canada's ultimate parent. Enron Canada was not itself insolvent.

\section{FACTS}

An application was brought by Enron Canada under s. 192 of the Canada Business Corporations $\mathrm{Act}^{\text {ss }}$ seeking an order from the Court allowing it to continue in business as a marketer and trader of natural gas and electricity, notwithstanding the financial collapse of its indirect parent company, Enron Corporation, which was under Chapter 11 protection in the United States.

As a result of the financial collapse of Enron Corporation and the concomitant effect on its credit rating, a number of counterparties had terminated or were terminating their Enron Canada contracts, leaving Enron Canada without adequate supplies of gas and electricity to meet its contractual obligations. Enron Canada was seeking an order from the Court staying the termination rights of the counterparties and requiring them to continue to perform their contractual commitments, pending Enron Canada's substitution of a new creditworthiness guarantee or guarantees for those of Enron Corporation.

Enron Canada proposed an order which would substitute new forms of security for the creditworthiness guarantee, which had been freely negotiated between the applicant and its counterparties, and which would suspend the termination and netting out rights. These rights were, of course, also cstablished through arm's-length commercial arrangements.

\section{DECISION}

The Court held that while it had every sympathy for the position of Enron Canada, it must also have regard for the sanctity of contract and the detrimental effect of the order sought on the counterparties who had bargained for unsecured and vested contractual rights to protect themselves in the risky and highly volatile commodity markets.

The Court referred to Re Blue Range, which considered the same type of forward commodity contracts. In that case, the Alberta Court of Appeal cited with approval an earlier judgment of the Ontario Court (General Division) in the case of Confederation Treasury Services LId., (Trustee of) v. Hees International Bancorp, ${ }^{56}$ where the Ontario trial judge, in the words of Fruman J.A. of the Alberta Court of Appeal: "recognized that derivative contracts are a legitimate method of managing risk and as a matter of public policy should not be dealt with in a manner that affects their efficiency either in non-insolvency or insolvency situations." $\$$ 
Justice Fruman went on to quote Farley J. directly from Confederation, saying that "[i]f the right to terminate contemplated in the agreement ... is not enforceable, the whole structure of risk management for the swaps and other transactions is weakened or may fall apart." ${ }^{58}$

The Court was being asked to assist a solvent corporation by giving it rights to suspend, amend or otherwise interfere with eligible financial contracts, while similar latitude is statutorily denied to insolvent entities. Just as there was good reason for the statutory exemptions in the insolvency legislation, there was equally good reason to honour the underlying public policy considerations in cases involving solvent applicants. In the result, the application was dismissed.

\section{COMMENTARY}

In this case, Hart J. affirmed the fundamental public policy principles that underlie the relatively recent amendments to the federal insolvency legislation (which parallel similar provisions of the United States insolvency statutes). These principles preserve the integrity and operation of derivative contracts by preserving, whether in solvent or insolvency circumstances, the contractual termination and netting-out provisions of such contracts. It would appear unlikely that any court in Canada would now accept any challenge to that policy as adopted both by Parliament and by the courts.

\section{B. BATEX ENERGY LTD. V. ENRON CANADA ${ }^{59}$}

\section{BACKGROUND}

This case is the next instalment in the ongoing Enron Canada saga. It is a mirror image of the previous case, Re Enron. In this case, the counterparties to Enron Canada's gas purchase and sale contracts sought the preliminary determination of an issue pertaining to their rights to enforce the termination and netting-out provisions in their contracts. Specifically, these contracts contained "one way" or "zero damages" clauses.

\section{FACTS}

The applicants entered into gas purchase and sales transactions pursuant to various contractual arrangements with the respondent, Enron Canada. Pursuant to the terms of these contracts, various triggering events occurred in November and December of 2001 entitling them to terminate the contracts. Declarations were sought that the termination of the contracts was lawful. It was alleged that gas was supplied under the contracts for which Enron Canada had failed to pay.

Enron Canada defended and counterclaimed. It alleged that the terminations were wrongful and that it was not indebted to the applicants for the gas supplied. Its counterclaim 
included, inter alia, claims for set-off, deficiency damages, early termination damages, restitution for unjust enrichment and relief from forfeiture.

The contracts that formed the subject of the applications provided for early termination upon certain triggering events arising from defaults of various kinds. The triggering events, in turn, lead to the calculation and payment of early termination damages and payments. Certain of the contracts contained what the applicants referred to as a "zero damages" provision. One example of such a clause was contained in clause 10.2 of an agreement between Enron Canada and Dominion Exploration Partnership as follows:

If the amount for any Transaction is a positive amount, then the Notifying Party shall be considered to have incurred a loss, and if the amount for any Transaction is a negative amount, then the Notifying Party shall be considered to have incurred a gain. The gains and losses for each terminated Transaction shall be netted: provided, however, if the net amount is a negative amount, the net amount of the Early Termination Damages shall be deemed to be zero. ${ }^{60}$

Based on this clause, the applicants argued that each of the zero damages provisions provided for "one way" termination payments. Enron Canada denied the enforceability of these zero damages provisions and asserted that a "two way" payment was required on termination of the contracts.

Each of the applicants filed a notice of motion seeking leave to have certain preliminary issues determined prior to trial pursuant to Rule 221 of the Alberta Rules of Court, ${ }^{61}$ although they requested that all of the issues be dealt with together in one preliminary hearing. The applicants argued that the determination of the issues was common to a series of eight actions. They suggested that these determinations would be simple and straightforward, could be heard in chambers with affidavits and briefs and would streamline the litigation and provide consistency in the eight actions. Enron Canada maintained that the determinations sought were extremely complex, required live evidence, were bound together with many of the "remaining" issues, and would complicate and delay the trial and would lengthen the litigation. In addition, it suggested that the overlapping issues and evidence would result in prejudice and injustice if a trial were to be split as was suggested by the applicants.

The question addressed by Hart J. was whether it was appropriate to determine the issues prior to trial pursuant to Rule 221. He quoted the five factors to consider in determining whether an issue should be tried separately under Rule 221, summarized in Leim Estate $v$. Home Insurance Co., namely:

Will it end the suit, at least if decided one way?

Will there be a saving in time or money spent on litigation, again at least if decided one way?

Will it create an injustice?

Are the issues complex or difficult?

Will it result in a delay in trial? ${ }^{62}$ 


\section{DECISION}

Justice Hart concluded that a preliminary determination of the selected issues would not end the actions, that it was unlikely that there would be a saving in time or money spent on litigation, that there was serious risk of injustice through a preliminary determination, and that the issues were complex and difficult and would likely result in a delay of the trial because an appeal of his determination was virtually certain.

\section{COMMENTARY}

This case is of interest in that it lays out many of the complex factual and legal issues arising from the termination and netting-out provisions of these gas purchase and sale contracts, with particular focus on those contracts that contain zero damages clauses. This case is significant as yet one more example in support of the proposition that the preliminary determination of an issue before trial is undesirable and is allowed in only the most exceptional cases. This was not one of them. This case is also evidence of what has occupied most of the insolvency litigation bar in Alberta throughout 2002.

\section{EMPLOYMENT}

\section{A. MOTHERSELE V. GULF CANADA RESOURCES LTD. ${ }^{63}$}

\section{BACKGROUND}

Legal counsel is frequently confronted with the question as to what an employee needs to have done for his conduct to amount to "just cause" for the purpose of termination without notice. During the past year, there have been several reported cases which are instructive on this point.

\section{FACTS}

Gulf Canada Resources Ltd. (Gulf Canada) dismissed the plaintiff (M), a senior staff engineer with nineteen years of service, as a result of a memorandum $M$ sent to the Chief Operating Officer (COO) of Gulf Canada. In this memorandum M stated: "I'll make sure I'll purge my files and memory banks so that I leave no tracks," a comment which Gulf Canada took to mean that $\mathrm{M}$ was threatening to destroy work product and files. The main issue at trial was whether Gulf Canada had just cause to terminate M's employment.

$M$ had often been outspoken in his criticism of both the management of Gulf Canada and its information management services (IM). In particular, $M$ was critical of Gulf Canada's system for storing reserves data and information. Gulf Canada had provided $M$ with a standalone computer that could also be used on the Gulf Canada's network. $M$ tended to store documents and information on the stand-alone computer and only back up the documents and information to the Gulf Canada's network once a year. This fact was known to both M's supervisor and the $\mathrm{COO}$ of Gulf Canada. 
In meetings with his supervisor and others, M's negative attitude was discussed, as well as the need for improvement in M's presentation and communication skills. $M$ was told that he would receive a double bonus, but that his salary increase would be deferred pending improvement in the identified areas. $M$ was also told that he had little room to progress on the technical level within Gulf Canada and that any further progression would require his involvement on a managerial level. $M$ felt that he was not being treated fairly and testified that he wrote the subject memo to get the attention of the COO. $M$ gave the memo to his supervisor to pass on to the $\mathrm{COO}$ late on a Friday afternoon after the $\mathrm{COO}$ had already left for the day. The supervisor presented the memo to the $\mathrm{COO}$ at the COO's home that weekend. On Monday morning, M's supervisor, the $\mathrm{COO}$ and the president of Gulf Canada met and decided to terminate $M$ 's employment based on what they felt was a security issue: a threat to Gulf Canada's property. The COO then directed M's supervisor to contact the IM department to take steps to back up the information on M's computer. $M$ was told of his termination the following day.

\section{DECISION}

Justice Nation began her analysis of the applicable law noting that for an employee's conduct to amount to just cause for termination, there must be conduct that is a breach of the employee's fundamental obligations, including serious misconduct, wilful disobedience to the employer's orders in a matter of substance, or conduct that is incompatible with the continued existence of the employment contract. The alleged misconduct is to be reviewed in the entire context of the employment relationship, and the test is that of a reasonable employer: "is the fault something a reasonable employer could not be expected to overlook, having regard to the nature and circumstances of the employment?"tot

Noting that, in this case the threat in the memo had to be evaluated in the context of M's earlier complaints, his criticism of management and the internal memo, the Court found that when the threat was made, $M$ did have data on his computer that was not backed up on Gulf Canada's system, and it was critical data relating to the reserves of the company. The Court also held that $M$ was capable of carrying out his threat. Despite this, and the fact that she accepted that Gulf Canada was concerned for its data, Nation J. applied an objective standard and found:

Considering all the evidenec, I find that the reasonable, objective employer faced with this type of memo, which crossed the line from the previous "disgruntled employee" memos, in that it threatened that if the employee had to do certain things, he would delete information, would have taken imınediate steps to back up and protect the employee's data that could be at risk, and assess the risk given all the circumstances of the employee, his employment contract, and the circumstances of his employment. Here, knowing the employee. knowing there was a possibility he did not mean to carry out the threat, knowing his technical skills and love of the work product, and knowing his personality, the reasonable, objective employer would not have immediately terminated [M]. The reasonable employer would have communicated the perceived seriousness of the threat by the employer and assessed the employee's state of mind and intentions, once it was established whether the "if" was required by the employer. 
Justice Nation then assessed the appropriate notice period at 15 months. However, as $M$ earned $\$ 147,816$ in net consulting fees during the notice period, which was $\$ 5,683$ more than his salary amount, no damages were awarded for loss of salary during the notice period. The Court did, however, award judgment of $\$ 40,206$ for bonuses, $\$ 33,275$ as compensation for stock option "damages," and $\$ 5,076$ for loss of benefits.

\section{COMMENTARY}

This case is just one more exasperating example in the search for what constitutes "just cause." If a threat in writing by an employee to destroy valuable data of great importance to the company does not constitute "just cause," then one has to wonder whether that concept even exists today under the current law, short of outright fraud or deceit. What the Court expected Gulf Canada to do in order to meet the reasonable employer test in this case appears to suggest that the benefit of any doubt will be decided in favour of the employee, not the employer.

This case was also a pyrrhic victory for the former employee. His relatively nominal damage award was no doubt taken up by his costs of litigation. Mitigation, as a result, is a powerful principle in the defence of a wrongful dismissal claim.

\section{B. VARSITY PLYMOUTH CHR YSLER (1994) LTD. V. POMERLEAU \\ 1. BACKGROUND}

Just when we thought that outright dishonesty was enough to constitute "just cause," we find that not necessarily to be so.

\section{FACTS}

The defendant (P) was an employee who held a management position at a car dealership. The dealership had a plan through which employees could purchase vehicles for personal use, and over a period of four years $\mathbf{P}$ had purchased fourteen vehicles through this plan. P's employment was terminated when it was found out that he had taken a truck from the dealership, driven it for a month and then sold it privately, without completing the paperwork required for purchases through the plan. The dealership commenced a debt action against $P$, and $P$ counterclaimed for wrongful dismissal.

\section{DECISION}

Although $\mathbf{P}$ had mislead the dealership as to the nature of the transaction with the truck, the dealership had tolerated P's previously sloppy and/or suspect use of purchases through the plan. The dealership had also tolerated another employee's sale of one of its older vehicles for personal profit, without any disciplinary measures, as well as the sexual harassment of one of its employees by another, without dismissing the offender. Thus, in determining whether P's dishonesty was serious enough to warrant a dismissal for cause, the 
"employer's particular business culture" ${ }^{67}$ - in this case, the dealership's tolerance for bad behaviour - had to be considered. The Court found that the dealership's dismissal of $P$ resulted in one employee being treated differently than the others in similar circumstances and, thus, constituted wrongful dismissal.

\section{COMMENTARY}

This case establishes that if dishonesty or otherwise unacceptable behaviour by an employee is part of an overall pattern within the employer company that has, for one reason or another, been tolerated, then that dishonesty or unacceptable conduct will not necessarily constitute "just cause." This is an important concept of which counsel should be aware, because it makes a strong case for every employer to set high standards for the expected conduct of its employees and then to stick to those standards. That may mean enforcement by dismissal for misbehaviour, even in circumstances where that misbehaviour could possibly be tolerated. Employers, however, should not expect that dismissals for misbehaviour will be considered as being for "just cause" if the employers have a history of tolerating misbehaviour.

\section{WINDSHIP AVIATION LTD. V. DEMUELLES ${ }^{68}$}

\section{BACKGROUND}

This case assesses the interesting issue of whether a non-competition covenant, that forms part of an employee's contract of employment is enforceable if that employee has been wrongfully dismissed. That is a particularly important issue in light of the comments in the previous two cases about the danger of unwittingly triggering a wrongful dismissal in circumstances where the employer might well believe that there is a "just cause" for dismissal.

\section{FACTS}

An employee that was dismissed for alleged cause was hired by a competitor of the original employer four months later. An agreement that the employee had signed with its former employer contained a non-competition provision that was to have had an effect for three years. The employer brought an action against the former employee and the competitor and sought an interlocutory injunction preventing the employee from working for the competitor.

\section{DECISION}

Referring to case law dealing with the appropriate test for an injunction in these circumstances, and in particular the first part of the tripartite test set out in RJR-MacDonald Inc. v. Canada (A.G.). ${ }^{69}$ Macklin J, stated that: 
given that restrictive covenants are prima facie to be considered void as against public policy and that the practical effect of them may be to prevent an individual from being employed in his chosen profession, I agree that the stricter standard is required of an Applicant seeking an interim injunction on the strength of a restrictive covenant. Accordingly, the Applicant here must not simply show that its action is not frivolous or vexatious but it must show that it has a strong prima facie case on the merits. ${ }^{70}$

In assessing the strength of the employer's case on the merits, Macklin J. cited J.G. Collins Insurance Agencies Ltd. v. Elsley Estate, " noting that the Court must first look at the restrictive covenant in the agreement, as it is enforceable "only if it is reasonable between the parties and with reference to the public interest." 2 While the Court felt that the employer could satisfy the requirements for establishing the reasonableness of the non-competition clause, it was troubled by the manner in which the employer had effected its warnings and subsequent termination of the employee. The Court found that the waming letters prior to termination of the employee were ambiguous and inconsistent. Under such circumstances, the employee's termination would be unfair and would constitute a wrongful dismissal. Due to such wrongful dismissal, the non-competition covenant would be unenforceable. Accordingly, the Court decided that the employer had not made out a sufficiently strong prima facie case for an injunction.

\section{COMMENTARY}

Many employers in the oil and gas industry today seem to take great solace in having noncompetition covenants and other similar restrictive covenants in their employment agreements with key employees. This case once again emphasizes the fundamental principle that all such covenants are prima facie to be considered void as against public policy, unless the employer can meet the heavy onus of establishing that they are reasonable in the circumstances. Even when they are found to be reasonable, and because of that overriding public policy, there are instances where the court has found a basis for denying the enforceability of these clauses. This is another example that illustrates the frequent lack of legal efficacy of non-competition clauses.

\section{Occupational Health and Safety}

\section{A. R. V. GENERAL SCRAP IRON \& METALS LTD. ${ }^{73}$ \\ 1. BACKGROUND}

The question in this case has to do with employee safety. What part does industry standard practice play in determining what is reasonably practicable to preserve the health and safety of a worker? 


\section{FACTS}

An employee of the defendant died when a bale of scrap wire fell on him from a stack of four such bales while he was working near the stack. The defendant was charged and found guilty in Alberta Provincial Court under the Occupational Health and Safety $\mathrm{Acl}^{74}$ and its regulations of the following: (1) failure to ensure "as was reasonably practicable the health and safety of a worker"7s and (2) "failure to take all reasonable steps to ensure that such materials were contained or restrained to eliminate the potential danger"76 related to "a potential danger of dislodgment, or movement of materials, to wit: bales of wire." The defendant appealed the findings, stating that the trial judge erred by assigning no weight to the evidence offered as to industry standard practice in the stacking of bales of scrap wire, by using an erroneous test for foreseeability and by rejecting the defendant's due diligence defence.

\section{DECISION}

Justice Watson disagreed that the Court below erred in its consideration of the industry standard, stating that such information was not ignored but instead that the trial judge "found it unpersuasive on the key questions." While noting that the government could have imposed more precise or exacting standards to be followed with respect to the stacking of such bales, Watson J. observed that this did not absolve the defendant from achieving the type of reasonable conduct required by the Health and Safety $A c t$ and its regulations. He stated: "Whether or not the bale stacks were generally four high in the industry was primarily a matter of efficiency in the use of available storage space, and not decisive as to whether it was hazardous to work next to them."

\section{COMMENTARY}

The important principle arising from this case is that when worker health and safety is at stake, proof that standard industry practice was followed is not necessarily sufficient to establish that the employer took all steps reasonably practicable to ensure worker health and safety. That means that the safety of personnel on any project must look at every aspect of the work, purely with a view to safety and without being unduly influenced by standard practices. 


\section{ENVIRONMENTAL LAW}

\section{A. R. V. PETRO-CANADA ${ }^{80}$ \\ 1. BACKGROUND}

This appeal raised two questions of law concerning the application of the due diligence defence to a strict liability charge. The first was whether, to engage the defence, an accused must prove the precise cause of the particular event giving rise to the charge to show in order that the preventative steps taken constituted all reasonable care. The second involved the onus of establishing the defence and who bears that onus.

\section{FACTS}

Petro-Canada was charged with the offence of discharging or causing or with permitting the discharge of a contaminant, namely gasoline, into the natural environment that caused or was likely to cause an adverse effect, contrary to s. 14(1) of the Ontario Environment Protection Act. ${ }^{81}$ At trial, the Court found that a spill of gasoline had occurred during the relevant dates at Petro-Canada's premises in Thunder Bay, Ontario. The spill resulted from the failure of a pipe at the point where it was passing through an earthen berm. The spread of the spilled gasoline was compounded by the actions of two of Petro-Canada's employees.

The trial judge concluded that the Crown had proven all of the essential elements of the offence. Having determined that this was a strict liability offence, he then turned to the defence of due diligence. He found that Petro-Canada had a number of safety systems and procedures in place both to prevent a pipe failure and, if such a failure occurred, to detect it quickly and to mitigate its effects. However, he stated that he was unable to apply the due diligence defence in this case because there was no evidence before him explaining why the pipe had failed. Without that, he could not determine if Petro-Canada had taken reasonable care. Since Petro-Canada had not proven that part of the case, the trial judge found that the defence had not been made out. Consequently, he concluded that there must be a conviction.

On appeal to the Ontario Court of Justice, Sargent J. disagreed with the view of the trial judge that the defence of due diligence could not be applied in this case because the cause of the pipe failure was unknown. He reviewed the evidence at trial about the safeguards that Petro-Canada had in place to prevent such an accident, and concluded that the defence of due diligence had been established.

\section{DECISION}

The Ontario Court of Appeal commenced its analysis by reference to the seminal judgment of Dickson J. (as he then was) in $R v$. City of Sault St. Marie. ${ }^{32}$ There he expressed the famous passage in which he distinguished a "middle ground" offence between the extremes 
of offences requiring proof of mens rea and those involving absolute liability. That passage is as follows:

\begin{abstract}
Offences in which there is no necessity for the prosecultion to prove the existence of mens rea; the doing of the prohibited act prima facie imports the offence, leaving it open to the accused to avoid liability by proving that he took all reasonable care. This involves consideration of what a reasonable man would have done in the circumstances. The defence will be available if the accused reasonably believed in a mistaken set of facts which, if true, would render the act or omission innocent, or if he took all reasonable sleps to avoid the particular event. These offences may properly be called offences of strict liability. ${ }^{83}$
\end{abstract}

The Court of Appeal held that it would be adding an additional burden to an accused charged with a strict liability offence if the accused also had to prove the precise cause of the event. The Court commented that, of course, if the accused could prove the precise cause, that would narrow the scope of what it would have to prove to establish that it had exercised due diligence to avoid the commission of the offence. In cases such as the present one, however, where the accused could not prove the precise cause of the event, it would have to establish that it took all reasonable care to avoid any foreseeable cause. Consequently, the accused would be unable to narrow the range of preventative steps that it would have to prove having taken. A new trial was ordered.

\title{
4. COMMENTARY
}

This is an important case in clarifying a misunderstanding of the strict liability offence and the defence of due diligence that must be proven to avoid conviction. The bottom line, from an operator's point of view, is that to be able to defend strict liability charges arising from unforeseen environmental mishaps, all operations must be conducted strictly in accordance with the best industry standards as well as in accordance with all statutory and regulatory requirements. Even that may not be enough in some cases, however, and the company should have in place its own operations and safety manuals that contemplate all of the steps that might reasonably be taken to avoid all mishaps that might be reasonably foreseeable.

\section{FreEIIOL.D LEASES}

\section{A. FreyberG V. FletCher Challenge OIL AND GAS $S^{84}$ \\ 1. BACKGROUND}

Following deregulation in 1986, many producers had shut-in wells that had been left in that state for lack of an available market or, in some cases, an economic or profitable market. Following deregulation, however, the availability of markets was no longer an issue. Deregulation gave rise to the question of whether such wells on lands subject to the relatively standard forms of "unless type" leases would be sufficient to create deemed production under such leases to continue their terms even where an economic or profitable market became available or shut-in royalties were not paid. 


\section{FACTS}

The plaintiff was the owner of an undivided two-thirds interest in a freehold natural gas lease dated 13 November 1975 (the Lease). During 1978, a well was drilled on the lands (6-3 well). The 6-3 well was left shut-in by the working interest owners for a period of more than 20 years from the time of rig release to the date when it was first put on stream in December 1999.

In 1987, the lessee placed another well (11-34 well), located approximately 0.8 miles from the 6-3 well, on stream from the same pool from which the 6.3 well was a prospective producer. The 11-34 well and another well a short distance away, also producing from the same pool, were produced for a number of years by the lessee until they watered out. The 6-3 well, however, being higher on the structure, was not entirely drained by the earlier production from the adjacent wells.

The plaintiff commenced an action seeking a declaration that the Lease terminated by its own terms, arguing that deemed production ceased after 1986 under the shut-in gas well clause of the Lease, because:

- there was no lack of an economical or profitable market for natural gas that could have been produced under the terms of the Lease between 1986 and 1999; and the defendants could not show that there was payment of a shut-in royalty under Clause 3 of the Lease on or before the November 13th anniversary date of the Lease for the years 1993 and 1996.

The Lease contained a shut-in well clause. This clause stated that if there is no producing well on the lands at the end of the primary term or the extended term of the Lease, but there is a well designated as a gas well on the lands and the well is not produced as a result of the lack of an economical or profitable market, the well shall be deemed to be a producing well and the lessee shall, on or before each anniversary date, pay a shut-in royalty to the lessor.

The Lease also contained a relatively standard default clause, which provided that in the case of the breach or non-observance by the lessee of any covenant or other stipulation in the Lease, the Lease may be terminated on 90 days' notice. This applied provided that the Lease would not terminate if on the lands there is located a well capable of production, in which case the lessor's remedy for any default shall be in damages only.

\section{DECISION}

Justice Romaine made a number of findings which will be of significant interest to lessors and lessees alike. These will be addressed under several headings below.

\section{a. Onus of Proof of Payment of Shut-in Royalties}

There was a dispute as to whether there had been timely, or any, payment of shut-in royalties in 1993 and 1996. The Court held that the best evidence on the question of these payments must come from the lessees, who have control over the internal documentation and record-keeping. They, therefore, have the onus of proof with regard to those payments. 


\section{b. Payment by Cheque of Shut-In Royalties}

The Lease contained a "manner of payment" clause. It provided for deemed payment by cheque delivered to a depository. The lessee purported to make payment of shut-in royalty for at least one of the years of the Lease's protracted shut-in period by post-dated cheque. The Court held that this cheque had been sent to the depository. A query, however, is whether the delivery of a post-dated cheque is sufficient to achieve deemed delivery of shut-in payment under the "manner of payment" clause. The Court held that payment by post-dated cheque was sufficient and that a post-dated cheque was a "cheque" for the purpose of the "manner of payment" clause. Case authorities suggest that a post-dated cheque is not a cheque for the purposes of the Bills of Exchange Act. ${ }^{85}$

\section{c. Onus of Proof with Respect to the Existence of an Economical and Profitable Market for Gas Production}

It was the plaintiff's contention that the Lease had expired because there was no lack of an economical and profitable market for the gas production from the 6-3 well following deregulation. That was over the considerable period after 1986 and until the 6-3 well was actually put on production in 1999 . When put on production, the 6-3 well was highly productive and highly profitable. The plaintiff argued that the lessee's production from the two wells, located a very short distance away and producing from the same pool, was proof that there was an economical and profitable market for this production.

The Court held that the onus was on the lessor to establish the existence of an economical or profitable market for the gas production from this well. To that extent, the Court departed from the earlier decision of the Alberta of Court of Appeal in Blair Estate Lid. v. Altana Exploration ${ }^{86}$ as well as the Alberta Court of Queen's Bench decision in $549767 \mathrm{Alberla} \mathrm{Lid.}$ v. Teg Holdings Lid. ${ }^{87}$

d. Did the Lease Terminate as a Result of a Failure by the Lessee to Produce the 6-3 Well at a Time When There was an Economical and Profitable Market for Production?

In determining this point, the Court quoted from an Oklahoma case, Herbert.J. Danne v. Texaco Exploration and Production Inc.:

... Automatic termination of the lease [in the primary term] ... does not divest the lessee of valuable assets, since no assets have yet been proved ...

Occurrences of limiting conditions in the secondary lease term are trealed differently.... No automatic termination of the lessee's estate can be tolerated at this stage in one [sic] life of the lease, because the lessee has proved a valuable asset and has established a right to develop that asset ... the lessee in the secondary term must be given a reasonable opportunity to develop the asset without fear of forfeiture. ${ }^{88}$ 
While the Court did not adopt the decision of the Oklahoma Court in its entirety, it accepted the reasoning in that case that different equities should apply when a lessor attacks the validity of a lease in the secondary term after the lessee has made major investments and taken substantial financial risk in developing a well. These findings appear to be a substantial departure from the existing jurisprudence developed over the last 50 years with respect to the operation of the freehold petroleum and natural gas lease.

\section{e. The Default Clause}

The Lease contained a default clause that provided that in the event of any breach or nonperformance by the lessee of any covenant, proviso, condition, restriction or stipulation, the lessor may give 90 days' notice thereof. Failure by the lessee to rectify the default within that period would result in a termination of the Lease. This is, however, provided that the Lease cannot be terminated if a well capable of production is located on the lands, in which case the lessor's remedy is limited to damages.

The Court distinguished cases like Canadian Superior Oils of Californiav. Kanstrup ${ }^{99}$ and Wolff $v$. Consumers' Gas, ${ }^{90}$ which held that such a default clause would be ineffective in preserving a lease in case of a failure to produce, since the lessee has no obligation under the lease to produce from the lands. The Court, however, distinguished those cases on the basis of very slight differences in the wording of the default clauses.

A similar argument that a freehold lease would be preserved by operation of the default clause was made in Durish v. White Resources Management Lid.," where Bracco J. (as he then was) found that the shut-in royalty clause in that particular lease was not a covenant imposing an obligation on the lessee to produce, such that the default clause would have no application. Justice Bracco characterized the shut-in well clause as an option in favour of the lessee to extend the term of a lease by putting the well on production in circumstances where there is an available market. Justice Romaine, however, declined to follow that case because the case reports of Durish did not disclose the actual text of the lease in that case.

\section{f. Was there an Economic or Profitable Market for the 6-3 Well}

During the Time it was Shut-in?

The Court addressed whether there was an economic or profitable market for the 6-3 well during the time it was shut-in, in case it was wrong on the effect of the default clause. In doing so, the Court held that reference to an economic or profitable market must be seen from the perspective of the lessee, and therefore would include reference to the cost of drilling, equipping, completing and operating the 6-3 well. This would include costs of gathering facilities and marketing of production. In addressing the perspective of the lessee, the Court applied a highly subjective test, describing it as being similar to the business judgment rule used by the courts in reviewing the actions of corporate boards of directors, such as in Canada Southern Petroleum LId. v. Amoco Canada Petroleum. ${ }^{92}$ 
The facts in this case, however, were that Apache Canada Ltd. (Apache), and its predecessors in title, were the only named lessees under the Lease. Over the years its predecessors had farmed out the lands so that a number of other companies had acquired working interests, but none of them were ever formally recognized as lessees under the Lease. In applying its subjective test, the Court considered and applied the opinions and conclusions of Tudor Corporation Ltd. (Tudor), which was the operator of the 6-3 well during the relevant time, although not a named lessee. The Court considered the views of Tudor at the time and concluded that Tudor's decision that the 6-3 well could not be economically or profitably produced was reasonable. That was to be contrasted to the testimony of a former employee of a predecessors of Apache whose view of the economics and profitability of production from this 6-3 well were very different. This was particularly since his employer, the named lessee under the Lease, was putting the adjacent 11-34 well on stream simultaneously to produce from the same pool. It may be notable that such named lessee had a considerably higher working interest in the 11-34 well than it did in the Tudor-operated 6-3 well. Tudor had approached the operator of the 11-34 well to seek permission to tie-in the 6.3 well but was turned away. It did not take any steps that would have been available to it under the Oil and Gas Conservation $\mathrm{ACl}^{93}$ in the face of the competitive drainage. Nevertheless, the Court held that Tudor's decision that the 6-3 well could not be economically produced was reasonable.

\section{COMMENTARY}

At the time of publication, this case has been appealed to the Court of Appeal and was scheduled to be heard in December 2003. If the principles adopted by the trial judge are affirmed on appeal, this case will herald a tidewater change in the interpretation of the "unless type" freehold lease.

\section{B. MONTREAL TRUST V. WILLISTON WILDCATTERS ${ }^{94}$}

\section{BACKGROUND}

This case also considered the termination of a petroleum and natural gas lease during the secondary term of the lease. This case was discussed by Edward A. Leew and Michael A. Thackray in "Recent Judicial Developments in Oil \& Gas Law." Since publication of that paper, the application for leave to appeal to the Supreme Court of Canada from the decision of the Saskatchewan Court of Appeal, ${ }^{96}$ which affirmed the Saskatchewan Court of Queen's Bench decision, ${ }^{97}$ was dismissed with costs. 


\section{Guarantees}

\section{A. SASKaTCHEWAN WHEAT POOL V. STRAIT CROSSING GROUP LTD. ${ }^{98}$ \\ 1. BACKGROUND}

At common law, there are a myriad of defences available to an action against a guarantor. This case illustrates some of those defences and the necessity of very careful drafting in the preparation of such guarantees in order to exclude, as much as possible, common law defences.

\section{FACTS}

This was an application by Saskatchewan Wheat Pool (SWP) for summary judgment on a guarantee signed by $A$, the company controlling the defendant Strait Crossing Group Ltd. (Strait). The parties agreed that Strait was to purchase SWP's interest in a project in Poland and $A$ was to guarantee Strait's payment of the purchase price. When Strait failed to pay the amount owing under a promissory note delivered as part of the purchase price, SWP made a demand for payment to $A$ pursuant to the guarantee executed by $A$. A refused, stating that SWP had failed to provide certain documentation under the terms of the arrangement. SWP then sued Strait and A to enforce the agreement, the promissory note and the guarantee.

\section{DECISION}

The Court dismissed the application for summary judgment, stating that SWP's compliance with the terms of the agreement was a material fact that was at issue in this dispute. The Court went on to say that if A were to establish successfully at trial that SWP did breach the terms of the agreement by refusing to provide the subject documentation, and if that breach had significant or substantial impact on Strait, then A, as guarantor, may have a defence to a claim for payment of some, or even all, of the purchase price.

\section{COMMENTARY}

The important practice point arising from this case is that guarantees, in relation to a material commercial transaction, should be separately drawn and carefully crafted to exclude possible common law defences. From the other point of view, of course, this case alerts us to the kinds of defences available to guarantors when there is something amiss in a transaction between the creditor and the principal debtor. 


\section{B. DRYCO BUILDING SUPPLIES V. WASYLISHYN}

\section{BACKGROUND}

This case raises an interesting question concerning the effect of taking a covenant from a corporation that has lost its corporate status by being struck from the corporate register.

\section{FACTS}

The plaintiff (Wasylishyn) entered into a contract with Dryco Building Supplies (Dryco), the defendant company, to provide drywall and insulation materials on credit. Neither party was aware that the defendant company had been struck from the corporate registry. The individual defendants, who were principals of Dryco, had also executed the credit agreement. When the account went into default, the plaintiff issued a statement of claim against the individual defendants, arguing that the credit application was in the nature of a personal assurance by the individual defendants. The individual defendants took the position that any personal guarantees would be void for lack of the certificate prescribed under the Guarantees Acknowledgement $A c t .{ }^{100}$ In the alternative, the defendants argued that the nature and effect of the personal covenant was misrepresented to them by the plaintiff's employee.

\section{DECISION}

Although Dryco was not in existence when the credit agreement was signed, Lee J. found that the individual defendants would be liable as agents of that non-existent principal. Furthermore, the subsequent revival of the defendant company did not extinguish the right of action acquired before that revival. The Court found that the individual defendants' obligation in the credit agreement was in the nature of an indemnity rather than a guarantee. since the liability of the individual defendants was not conditional upon any act or omission on the part of the corporate defendant. Accordingly, he held that no Guarantees Acknowledgement ACt certificate was required. With respect to the allegation of misrepresentation, the Court found that the credit agreement was sufficiently clear on its face and that the plaintiff was under no obligation to explain the nature and effect of the document.

\section{COMMENTARY}

Practitioners dealing with any instrument that may be construed as a guarantee granted by an individual in the Province of Alberta must take great care to remember the certificate under the Guarantees Acknowledgement Act. In this case, the document was interpreted to be an indemnity rather than a guarantee. Consequently, the individuals were held to be primarily liable in their own right such that a certificate was not required. This case also illustrates the importance of ascertaining the current status of any corporation entering into a material commercial transaction. 


\section{SURface Rights}

A. ZUBICK V. CORRIDOR PIPELINE LTD. ${ }^{101}$

\section{BACKGROUND}

In January 2001, the Alberta Surface Rights Board (ASRB) released a decision in relation to a hearing to determine the compensation payable by Corridor Pipeline Limited (Corridor) to a group of landowners who were subject to right-of-entry orders for the construction of a dual pipeline system from the Shell/Chevron property north of Fort McMurray to Scotford, Alberta. Corridor and the landowners appealed the decision of the ASRB to the Alberta Court of Queen's Bench by way of a hearing de novo. Corridor believed that the award was too generous. The landowners sought annual compensation from Corridor for the rights surrendered.

\section{FACTS}

The owners found themselves in a unique position because of their lands' location. Geographically, their lands occupied a strategic position between the Fort McMurray area and the highly-industrialized area around Fort Saskatchewan. Consequently, their lands had been entered several times in the past, with or without permission, for the purpose of constructing some form of pipeline. Many of these properties already had two or three linear disturbances beneath them before they were approached by Corridor.

The thrust of the landowners' appeal was to seek annual compensation for a pipeline installation. Normally, there is a one-time payment for a pipeline right-of-way. The landowners forcefully argued that because their lands and the required pipeline right-of-way fell within an active transportation and utility corridor between the Fort McMurray and Fort Saskatchewan areas, normal pipeline compensation was not appropriate.

In this case, Sanderman J. gave one of the most articulate explanations of a landowner's attachment to the land by underlining the great care that must be taken by operators who, by statute, have the right to force their way onto the land, even in the face of the landowner's objections. He said:

Many owners have a strong emotional attachment to their land. In this appeal 1 heard evidence from a number of people whose connection to their property had a spiritual quality. The property had been in the possession of family members for a number of generations. It was being held by the present owners for the next generation. These were people with a purpose. These were people who worked the land. They expected it to be worked by future generations. From their perspective this was not land given to them by their parents but was land lent to them by their children. One can appreciate the feelings aroused in people so closely connected to the land by a seemingly uncaring operator who can take rights associated with the land from them without their permission. If the operator or its agents are highhanded in their dealings with the owner these negative feelings are exacesbated. ${ }^{102}$ 
The Court commented in this case that Corridor was extremely responsible in its dealings with the landowners. The frustrations of the owners were traced by the Court, however, to the attitude exhibited by a land agent who was employed to negotiate access and compensation.

\section{DECISION}

The Court's reference to certain comments from the ASRB in this case illustrates the importance of taking great care in dealing with landowners concerning all aspects of the petroleum and natural gas industry. The ASRB commented that these landowners had made a "very compelling case for annual compensation." 103 The ASRB stated that it found those arguments persuasive and that it gave "very serious consideration"104 to going that route. To do so would herald a very major change in approach and in the costs relating to surface operations in the Canadian oilpatch. The ASRB concluded, however, that it was not prepared to award annual compensation "at this time." "10s

In the end, the Court accorded substantial deference to the decision of the expert board. Annual compensation was denied but the compensation was increased from $\$ 1,000$ to $\$ 1,200$ per acre.

\section{COMMENTARY}

In the State of California, operators wishing to install a new pipeline have found that it has now become virtually impossible to do so because of landowner objections and cost. Consequently, new lines must be installed in existing rights-of-way, which often involves removing and reinstalling pipe in the existing right-of-way.

This case illustrates the building tension between surface landowners and energy operators in Canada today. It highlights for operators the absolute importance of reasonable and evenhanded dealings with landowners. To avoid, or at least to delay, the situation that has evolved in California, operators must continue to increase their efforts to achieve satisfactory resolutions with the surface landowners. From the comments made by the ASRB, as well as by the Court in this case, it would appear that annual compensation for pipeline right-of-way, which has always been anathema to industry, may not be far away. 


\section{RIGIITS OF FIRST REFUSAL}

\section{A. CHASE MANHATTAN BANK OF CANADA V. SUNOMA ENERGY $Y^{106}$}

\section{BACKGROUND}

The fairness or reasonableness of allocation of value as between those parts of a property package that are subject to a right of first refusal, on the one hand, and the remaining parts that are not so subject, has been a long-standing issue in the petroleum and natural gas industry. In reality, the reasonableness of that allocation is very much dependent on the integrity of the vendor and its intended purchaser. Too often, vendors purport to delegate that responsibility for allocation to an intended purchaser. In that context, the views expressed by the Alberta Court of Appeal in this case are useful.

\section{FACTS}

This case involved the determination of the rights of a holder of a right of first refusal (ROFR) in circumstances in which the grantor of the ROFR went into receivership and the lands to which the ROFR attached were subsequently put up for sale by the grantor's receiver as part of a package deal that included other lands.

Sunoma Energy (Sunoma) and Best Pacific Resources Ltd. (Best Pacific) were successors in interest to the parties under a farmout agreement that incorporated $\S 2401$ of the 1974 CAPL Operating Procedure, ${ }^{107}$ which gave each of them ROFRs over certain lands. Sunoma went into receivership and the receiver, PriceWaterhouse-Coopers Inc. (PWC), divided Sunoma's assets into ten parcels and put the parcels up for sale. Parcel 6 included the lands upon which Best Pacific had a ROFR and working interests of approximately 80 percent (the ROFR lands).

Eravista Energy Corp. (Eravista) offered to purchase Parcel 6 for a price of $\$ 1,000,000$, causing PWC to issue a ROFR notice to Best Pacific. The notice specified that Best Pacific had 20 days in which to exercise its ROFR on the terms and conditions offered by Eravista. Best Pacific wrote to PWC (within the 20-day notice period) claiming that, based on an independent engineering report that it had commissioned, the ROFR Lands were worth only about $\$ 30,000$; therefore, the ROFR notice did not comply with the CAPL Operating Procedure. Upon expiry of the notice period, a court order approved the sale to Eravista. Best Pacific then applied for an injunction to prevent the sale.

The chambers judge held that Best Pacific was entitled to a ROFR notice, but that the notice had been issued properly and that Best Pacific had failed to exercise its rights under the notice in time. Referring to the range of values that Best Pacific had given to the ROFR Lands, as cited in an affidavit by Best Pacific's Vice-President and a consulting company's report, the Court concluded that mere difference in values did not show bad faith. The chambers judge noted that Best Pacific had not provided evidence of an evaluation as to any 
or all of the other properties in Parcel 6, which evidence might have supported its contention that the ROFR lands were grossly overvalued. He also noted that assigning a different value to the ROFR lands might have an impact on other lands in the package, putting the Court in the awkward position of having to shift values to other interests within the parcel. Lastly, the Court noted the general requirement that there must be strict compliance with the terms of a ROFR notice and that Best Pacific had taken no action within the notice period, other than having sent a letter to the effect that the notice was invalid. The Court held that, at a minimum, Best Pacific should have filed a notice of motion within that time. Not having done so, it had lost its rights under the ROFR.

\section{DECISION}

The Court of Appeal noted that much has been written regarding the issue of pricing lands subject to a ROFR when the lands are offered for sale as part of a package, stating that

[i]n brief, it has been suggested that, when lands subject to a ROFR form part of a package sale, it is not always apparent what value ought to be allocaled to the ROFR lands. For example, the purchaser of a package of lands may be willing to pay more than it would have paid for a single parcel, since there may be advantages 10 owning the package that enhance the value beyond that of the single pareel. On the other hand, there is a concern that the vendor and proposed purchaser may allocate value to the ROFR lands in such a way as to discourage the holder of the ROFR from exercising its rights. ${ }^{108}$

The Court also noted that the 1974 CAPL Operating Procedure did not account for this situation, simply requiring the vendor who has received "an offer which it is willing to accept" ${ }^{09}$ to notify the ROFR CAPL holder of "the terms and conditions"' 110 of the proposed sale. Although later versions of the Operating Procedure arguably provide for dispute resolution mechanisms in such circumstances, the 1974 CAPL Operating Procedure only provided for dispute resolution where the consideration for an offer could not be "matched in kind."'l!

Addressing Best Pacific's first argument that including the ROFR lands in a package sale meant that the proposed price was not a bona fide estimate of value, the Court noted that:

[a]t least one American court has held that selling a lot to which a ROFR attaches as part of a larger uransaction denies the ROFR holder the very nature of its right because it is impossible for the ROFR holder to verify the exact terms and conditions of the proposed sale: Gyurkey v. Babler, 65I P.2d 928 at para. 24 (Idaho Sup. Ct. App. Div. 1982).

We are not prepared to go that far in this case, especially since the parties to the appeal agreed to put three very narrow questions to the Court of Queen's Bench. ${ }^{112}$ 
The Court rejected Best Pacific's second argument that the proposed purchase price cannot be considered a bona fide estimate of the value of the ROFR lands because Eravista refused to reveal the basis of its valuation of those lands. The Court noted that it is far from obvious that Eravista owed a duty of good faith to Best Pacific. There was no privity of contract between them.

Repeating the chambers judge's findings, the Court stated that Best Pacific did not provide an independent valuation of the other properties in Parcel 6, a valuation which could have supported its contention that the value of the ROFR lands was distorted in the ROFR notice. The Court repeated the chambers judge's finding that assigning a different value to the ROFR lands could impact the value allocations elsewhere in Parcel 6, and could impact another party's ROFR.

In order to grant Best Pacific's request, the Court stated that it would have had to see more evidence that the receiver or Eravista breached their duty of good faith: "It is simply not enough for the ROFR holder to present a different valuation from that provided in the ROFR notice."113

\section{COMMENTARY}

Regrettably, for those who have sought more direction from the Court on this constant issue, the unique facts of this case and circumstances in which this case was heard have not resulted in direction from the Court that will be of particular assistance to practitioners. We will have to await a case involving a more satisfactory fact pattern the Court may be able to make the point emphatically that ROFRs cannot be circumvented lawfully in "package sales" by unduly "heaping" a disproportionate amount of the value onto the lands subject to the ROFR.

\section{Royalties}

\section{A. NATIONAL TRUSTV. JOHNSON ${ }^{1 / 4}$}

1. BACKGroUnd

Solicitors must always be careful to ensure caveats adequately describe and provide sufficient particulars of interests being claimed in the land that is to be protected by the caveat.

\section{FACTS}

The Tyhys, as owners and lessors, and the California Standard Company, as lessee, entered into a lease of certain lands dated 14 February 1950 (the Lease). The Lease expired 14 February 1960, and could no longer be located. 
The Tyhys, as owners, entered into a Royalty and Mineral Trust Agreement dated 14 November 1951 (the RMTA) with the applicant as trustee and Catawba Oil Explorations Company as purchaser. The applicant then registered a caveat against the land, purportedly respecting its interests under the RMTA. The Johnsons became the registered owners of the land as the result of two separate transactions during 1972 and 1977.

The RMTA gave the applicant two separate interests or rights, both of which were interests in land capable of protection by caveat, namely, the 12.5 percent interest in mines and minerals and the gross royalty. The caveat stipulated that the applicant claimed an interest in the land by reason of the RMTA, under the terms of which the owners agreed to transfer unto the applicant an undivided 12.5 percent of the mines and minerals within, upon, or under the Land. The Caveat was silent as to the gross royalty and by its language gave no suggestion of any other right or interest claimed.

The applicant sought a declaration that the RMTA was a valid and subsisting royalty and mineral trust agreement and that the caveat was a valid and subsisting caveat. In addition, the applicant sought a declaration of entitlement to the benefit of the caveat and to continued registration of the same, and entitlement to receipt of the gross royalty assigned to it pursuant to the RMTA.

\section{DECISION}

The Court held that the caveat was valid, but only to the extent that it protected the applicant's 12.5 percent interest in the mines and minerals. The Court held that the caveat had never, and does not now, apply to or protect the gross royalty interest granted to the applicant under the RMTA. To that extent, the Court simply affirmed the principle enunciated by the Supreme Court of Canada in Ruptash $v$. Zawick $k^{\prime \prime s}$ that parties dealing with land are entitled to assume that a claim to an interest as expressed in a caveat is the only claim made by the caveator - expressio unius est exclusio alterius.

The Court, by way of obiter dicta, also found that the assignment of the gross royalty under the RMTA was void for uncertainty.

\section{COMMENTARY}

Although the Court in this case commented that it is not necessary that a copy of an agreement or instrument creating a claim or interest in land be attached to the caveat, attaching the agreement is very often the best practical approach to achieve the objective of stating the full nature and particulars of a claim in the caveat. Alternatively, it sometimes makes sense to attach, and incorporate by reference, an expurgated copy of such an agreement where pricing or other confidential information needs to be obliterated for the sake of confidentiality. This, however, should be done in such a way as not to detract from the attachment as an effective means of fully describing the interest being claimed. 
XIV. SET-OFF

A. ALGOMA STEEL V. UNION GAS LTD. ${ }^{116}$

\section{BACKGROUND}

Although the law of legal set-off and equitable set-off is reasonably well-settled by virtue of cases such as Telford $v$. Holl ${ }^{17}$ and Re Blue Range, ${ }^{18}$ the petroleum and natural gas industry continues to generate factual patterns which give difficulty in the application of the established legal principles.

\section{FACTS}

This case involved the application of legal and equitable set-off in the context of the Companies ' Creditors Arrangement $A c t^{19}$ (CCAA). The contractual relationship in place between the parties Algoma Steel Inc. (Algoma) and Union Gas Ltd. (Union) during the relevant period is described below.

Under a previous contractual arrangement between the parties, Algoma had been required to pay for gas services in accordance with Union's rate schedule as approved by the Ontario Energy Board (OEB), which was based in part on the projected cost of gas. Depending whether this projection was too high or too low in any given year, Algoma may have either overpaid or underpaid Union. To account for this possibility, Union kept "deferral accounts" for its various classes of customers. In 1999, Algoma and the other customers in its class overpaid. Algoma was entitled to a rebate of approximately $\$ 2,200,000$. However, Union required OEB approval before it could repay its customers. Union applied to the OEB accordingly, but the OEB directed Union to continue to hold the balances in its deferral accounts until certain information regarding Union's 2001 and 2002 rates and deferral balances was finalized.

In October 2000, the parties entered into two new contracts: the 2000 Gas Services Contract and the Assignment Agreement. Both contracts had approximately the same term, from 1 November 2000 to 31 October 2001. In this new arrangement, Algoma no longer sold the gas to Union and repurchased it from Union in Ontario. Rather, Union assigned its right to access gas transportation capacity directly from TransCanada Pipelines Limited (TCPL) through Union's contract with TCPL. Algoma thus paid TCPL directly. Importantly, however, if Algoma failed to pay TCPL for use of gas transportation capacity it accessed, Union was required to pay TCPL. Algoma was then required to indemnify Union.

On 23 April 2001, Algoma obtained an initial order under the CCAA. As of that date, Algoma owed Union $\$ 461,244$ under the 2000 Gas Services Contract and, because Algoma had failed to pay TCPL for gas transportation services obtained by Algoma under the Assignment Agreement, Union was obliged to indemnify TCPL in the amount of $\$ 1,265,934$. 
These are the amounts that Union sought to set-off against the approximately $\$ 2,200,000$ owing to Algoma for the 1999 rebate.

At trial, in considering claims for both legal and equitable set-off, the Court noted that a pre-condition for legal set-off is that the obligations to be set-off against each other must be debts, that is, liquidated amounts. After reviewing the evidence, the Court concluded that the 1999 rebate owing to Algoma was not a liquidated amount.

In considering equitable set-off, the Court held that there was a close enough connection to establish equitable set-off concerning the gas supply portion of the 2000 Gas Services Contract with regard to any rebate which is authorized by the OEB. However, monies owing by Algoma to Union as a result of the I November 2000 Transportation Agreement were excluded. The Court therefore limited the equitable set-off to amounts owing under the $\mathbf{2 0 0 0}$ Gas Services Contract. Union appealed.

\section{DECISION}

The Court of Appeal noted that Algoma did not dispute that the law of set-off applied notwithstanding the CCAA proceedings, as s. 18.1 of the CCAA provides: "The law of setoff applies to all claims made against a debtor company and to all actions instituted by it for the recovery of debts due to the company in the same manner and to the same extent as if the company were plaintiff or defendant, as the case may be." ${ }^{120}$ While the Court of Appeal found that the trial judge's decision regarding legal set-off was supported by the evidence, it disagreed with his findings concerning to equitable set-off.

Citing the principles set out in Telford, the Court asked, "Is the 1999 rebate from the 1998 gas services contract so clearly connected with the amounts owing under the 2000 assignment agreement that it would be manifestly unjust to enforce payment of the rebate without taking into account the amounts owing under the assignment agreement?"'21

The trial judge found that the Assignment Agreement was integral to the 2000 Gas Services Agreement, but refused equitable set-off for amounts owing under the Assignment Agreement because it was not the same type of contract as the supply of gas by Union. The Court of Appeal, however, found that there was such a close connection between the 2000 Gas Services Contract and the Assignment Agreement that the amounts owing on one could not be separated from amounts owing on the other for the purposes of equitable set-off. Noting that the parties had agreed in the 2000 Gas Services Contract that it was to be "contingent upon" the Assignment Agreement, the Court held that it would be manifestly unjust to allow Algoma to insist on payment of the rebate arising under the former without allowing Union to set-off all the amounts owing under the 2000 Gas Services Contract as well as under the Assignment Agreement. 


\section{COMMENTARY}

It is instructive to note that, where possible, when two contracts are inextricably connected, it is a good idea actually to refer to each one in the other. In this case, the 2000 Gas Services Contract stipulated that it was "contingent upon" the Assignment Agreement. That detail proved to be of critical importance in bringing the debts owing under each of them into the equitable set-off, notwithstanding the fact that the Assignment Agreement, if examined alone, might not have been sufficiently connected to the rebate owing with respect to the 1999 deferral account (as had been found by the trial judge).

\section{TAXATION}

\section{A. CNG Producing V. Alberta (PRovinCIAL TREASURER) ${ }^{122}$}

\section{BACKGROUND}

There are strong presumptions against retroactive legislation, interference with vested rights and interference with pending litigation.

\section{FACTS}

CNG Producing Company (CNG) held oil sands leases from Her Majesty the Queen in Right of Alberta, upon which CNG was liable to pay production royalties. In 1985, the Provincial Treasurer established a policy that production from oil sands leases did not qualify for an Alberta Royalty Tax Credit (ARTC), because the royalties levied on oil sands were lower than those levied under conventional leases. However, this policy was apparently inconsistently applied and CNG successfully claimed an ARTC from 1985 through 1990. Although CNG received credits for the years 1991 to 1994, in 1995 the Provincial Treasurer reassessed CNG and denied the credits for those years. The Provincial Treasurer confirmed the reassessment following CNG's objection. CNG then filed and served notice of appeal on 17 June 1997.

In the interim, the Alberta Legislature passed the Corporate Tax Amendment $A c t,{ }^{123}$ which amended s. 26(I)(c) of the Corporate Tax Act. ${ }^{124}$ Section $26(1)$ (c) defined royalties that qualified for the ARTC and the amendment specifically excluded royalties, such as those levied against CNG, from qualifying for the ARTC. Furthermore, s. 4(3) of the Amendment $A c t$ stated that the new definition applied to all taxation years beginning after 31 December 1980. The Amendment Act came into force on 18 June 1997.

The chambers judge determined that CNG was not entitled to an ARTC on its royalties for the taxation years in question. She found that s. 4(3) of the Amendment Act was intended to operate retroactively and thus affected the taxation years in question. Further, she found that the presumption against interference with vested rights only applied where the impugned legislation was in some way ambiguous, which was not the case in this instance. Lastly, the 
chambers judge held that if the statute was declaratory of the law as it existed prior to the amendment, the amendment must be applied retroactively to litigation pending at that time. However, she was apparently not satisfied that the presumption against interference with pending litigation had been rebutted.

\section{DECISION}

The Court, in dismissing CNG's appeal, agreed with the chambers judge's finding that the legislature clearly intended the Amendment Act to operate retroactively. Thus, the presumption against retroactive application was rebutted.

Similarly, the Court noted that the presumption against interference with vested rights did not arise because the Amendment $A c t$ was unambiguous. The Court noted that in any event, even if CNG had acquired some vested rights to the ARTC prior to 18 June 1997, after that date those rights were governed by the amended law which operated retroactively and affected any vested rights.

The Court was also satisfied that the presumption against interference with pending litigation was rebutted simply by virtue of the retroactive effect of the legislation.

\section{COMMENTARY}

This case affirms the principle that although unusual, it is possible for the legislature to pass legislation that is sufficiently clear and precise to overcome the presumptions against retroactivity, interference with vested rights and interference with pending litigation.

\section{B. RAINBOW PIPE LINE V. CANADA ${ }^{123}$}

\section{BACKGROUND}

The distinction between expenditures that can be expensed in a single year as an operating cost from those costs that are of a capital nature for taxation purposes is an ongoing issue that affects all aspects of the industry.

\section{FACTS}

The sole issue on appeal was whether the trial judge erred in concluding that capitalizing the cost of a 44 kilometre replacement section in a 781 kilometre light crude pipeline belonging to Rainbow Pipeline (Rainbow) was more accurately characterized as relating to Rainbow's income for that particular taxation year, so as to preclude capitalizing the cost of the replacement. 


\section{DECISION}

The Court, noting that it found the trial judge's analysis and conclusions "unassailable," proceeded to dismiss each of Rainbow's seven arguments on appeal. Although accepting Rainbow's claim that the replacement pipeline was required for Rainbow to stay in business, the Court stated that there was no legal principle requiring that every expenditure necessary to stay in business must be expensed rather than capitalized.

The Court also found, according to well-accepted business principles, that simply because the replacement was not a betterment and did not enhance the operation of the pipeline, it did not necessarily require that the cost be expensed.

\section{COMMENTARY}

Although these findings may be of assistance in future cases, they do not overcome the ongoing frustration over the often-felt arbitrariness of what, in some cases, is a very fine distinction that nevertheless has very major monetary implications.

\section{MARKEVICH V. CANADA 126 \\ 1. BACKGROUND}

Now for some good news. This case addresses the interesting question as to whether federal and provincial limitations legislation affect collection procedures undertaken by the Canada Customs and Revenue Agency (the CCRA), formerly Revenue Canada.

\section{FACTS}

Stock promoter Joseph Markevich had heard nothing from CCRA for more than a decade on the subject of his $\$ 234,136.04$ tax debt. Then in 1998 , he was contacted by CCRA who informed him that he owed $\$ 770,583.42$ inclusive of interest for back taxes and that CCRA had decided to collect on his debt.

\section{DECISION}

Markevich's opposition to having to pay those taxes went to the Supreme Court of Canada, where it was held that CCRA could not collect upon its debt because it had let too much time lapse. The Supreme Court arrived at this decision by analyzing the relevant provisions of the Income Tax $A c^{127}$ (Canada) (the ITA) relating to the collection powers of the Crown. It found that since the ITA did not contain explicit limitation periods in its collection provisions, Parliament must have intended that limitation provisions of general application, such as those in the Crown Liability and Proceedings $A \mathrm{Cl}^{128}$ (Canada) (the 
CLPA) and in the Limitation $A c t^{129}$ (British Columbia), should apply to the collection of tax debts.

\section{COMMENTARY}

Although the Markevich decision has been widely hailed as a substantial victory for taxpayers - resulting from the outcome of the appeal, the federal government apparently stands to lose $\$ 1.26$ billion on other outstanding cases - the decision appears to have a limited application. For example, it does not mean that the Crown cannot go back many years to audit individual or corporate tax returns. The Crown is explicitly given that power by the ITA. Additionally, it does not affect the Minister's rights to reassess a taxpayer under a provision such as 5.160 of the ITA, which explicitly states that a taxpayer may be assessed for the tax owing "at any time." Furthermore, the Markevich principle will likely not apply if a taxpayer attempts to stall the Crown in seeking to collect a tax debt. Rather, it will only apply if the government makes no attempt to collect.

However, in the right circumstances, the principles in the Markevich decision may apply to cause a tax debt that has not been pursued in a prompt fashion by the federal or provincial government to be statute-barred. The principles in Markevich apply to federal tax debts which have not been acted on by the Crown before the expiry of the six-year period under the CLPA, or provincial tax debts which have not been pursued prior to the end of a provincial limitation period. Recall that in Alberta, for example, this limitation period under the Limitations $A c^{130}$ (Alberta) has now been reduced to an unrealistically short two-year period.

In the final analysis, the Markevich decision stands for the proposition that both federal and provincial governments are also subject to limitations legislation, unless otherwise expressly stated in the applicable legislation.

It is possible that the implications of the Markevich decision could go beyond the ITA. By extension, the Markevich principle and limitation periods, such as the six-year limitation period set out in the CLPA, are likely to apply to any type of royalty, fee or fine owed to the government, the collection of which is not subject to a clearly-stated statutory limitation period. The ruling in Markevich is significant in that the Crown, both at the provincial and federal levels, is subject to limitations legislation where the operative statute does not prescribe any other limitation or waiver of any limits on bringing an action or proceeding.

The federal government has not yet officially commented on the Markevich decision. The Supreme Court did, however, give a clear road map as to how Parliament might fix this problem on a going-forward basis: Parliament simply needs to include limitation periods within the collection provisions of the ITA and other legislation, or state clearly that there is to be no limitation. In addition, the governments might also be inspired by the Markevich decision to hire more collections staff. 


\section{INJUNCTIONS}

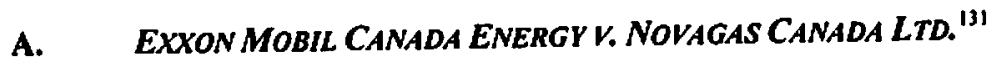 \\ 1. BACKGROUND}

The ground must surely have been shaking as three giants of the oilpatch squared off over an interim injunction. The issue was whether the tripartite sequential test for an interim injunction arising from the seminal case American Cyanimide v. Ethicon LId. ${ }^{132}$ applies in circumstances where the defendant is alleged to be in clear breach of a contractual covenant. Of course, whether or not there was such a clear breach was also in dispute in this case.

\section{FACTS}

Justice Wilkins granted an Order on 28 February 2002 (the Wilkins Order), which was entered on 12 March 2002, providing Exxon Mobil Canada Energy (EMC) with an interim interlocutory injunction against the defendants. The defendants, Novagas Canada Limited Partnership (NCLP), Novagas Canada Limited (NCL) and Solex Gas Processing Corp. (Solex), were enjoined from proceeding further with the implementation of the assignment of the interest of NCLP in the Representation, Management and Processing Agreement pertaining to the Harmattan Gas Plant (the Harmattan Plant) made between NCLP and Mobil Oil Canada dated 17 October 1997 (the Agreement) to Solex (the Assignment).

Since the application before Wilkins J. was made on three hours' notice from the plaintiff to the defendants (but not to their counsel), the application was, for all intents and purposes, made ex parte. With leave of Wilkins J., the defendants applied before Park J. for an order vacating the Wilkins Order and accordingly, permiting NCLP to proceed with the Assignment.

NCLP and EMC, by its predecessor, entered into the Agreement pursuant to which the parties agreed that NCLP would manage the interest of EMC in the Harmattan Plant and NCLP would process EMC's gas at the Harmattan Plant. EMC held a 56 percent ownership interest in the Harmattan Plant. EMC appointed NCLP its sole and exclusive agent with extensive rights on behalf of EMC with respect to EMC's ownership interest in, and rights in and to, the Harmattan Plant.

The Agreement provided that neither party may assign its interest without the consent of the other party and that such consent could not be unreasonably withheld. Further, the party assigning such interest was not released from any of its obligations under the Agreement unless or until the Assignee had been novated into the Agreement.

NCL did not obtain the consent of EMC before the Assignment. Justice Wilkins, in granting the injunction, found that there was a clear breach of the covenant in the Agreement not to assign without the consent of EMC. He rejected the defendants' submission that EMC 
had received sufficient information to provide consent. Rather, he held that EMC did not have sufficient information on which to base consent.

On the application to set aside the Wilkins Order, Solex, NCLP and NCL took the position that EMC was presenting a subterfuge in its position that it required more information on Solex before providing its consent to the Assignment. The defendants alleged that EMC's true position was that the request for consent of the Assignment was designed to enable EMC to force NCL and NCLP to resolve certain long-outstanding issues among EMC, NCL and NCLP.

The defendants advanced the position that while Solex may not have provided some corporate information relating to some of its shareholders and investors prior to 28 February 2002, that information was now set out in an affidavit filed on their behalf. This affidavit revealed that Solex was linked to the established Solex Development. Further, Solex shareholders included the management of Solex Development and 960345 Alberta Ltd., which was said to be indirectly controlled by N. Murray Edwards.

The defendants argued that the assignment of NCLP's interest in the Agreement to Solex did not relieve NCLP of its obligations to EMC under that Agreement. Absent a novation by EMC, NCLP would be, and would remain, contractually obligated for all matters that have arisen under the Agreement to date and into the future, irrespective of the assignment.

EMC conceded that it could not demonstrate irreparable harm. Hence, the tripartite sequential test as set out in $R J R$ MacDonald ${ }^{133}$ could not be met. Instead, EMC alleged that in assigning NCLP's interest under the Agreement to Solex, there was a clear breach of a clear negative covenant and, accordingly, EMC need not show irreparable harm.

In C.I.B.C. Development v. 724133 Alberla Ltd., ${ }^{134}$ the Court held that "[ $\left.t\right]$ he relaxation of the application of the tripartite test can only come out where there is a plain and uncontested breach. Where the Respondent disputes that there is such a breach and the evidence of it is not compelling, then a full examination of the entire tripartite test must be carried out." 135

The defendants cited Debra's Hotels v. Lee ${ }^{136}$ and $W-K$ Trucking $v$. Bidulock Oilfield Service LId. ${ }^{137}$ for the principle that the relaxation of the tripartite test should only be applied where the applicant's case is strong and there is little doubt on the merits. The defendants based their argument on the assertion that EMC unreasonably withheld its consent, and consequently, there was not a clear breach of a contractual covenant. 


\section{DECISION}

The Court held that the defendants could not merely raise in argument the words in their statement of defence alleging that the consent was unreasonably withheld. The defendants must present some evidence on the application to substantiate that pleading. However, the Court agreed with EMC that assigning the Agreement to Solex constituted a clear breach of a contractual covenant, and that, in the circumstances, a reasonable person would have refused to consent to the Assignment. The Court also held that EMC did not tie its consent to the Assignment to its position of desiring to resolve the outstanding historical issues among EMC, NCL and NCLP. EMC was held to be entitled to receive adequate financial information on Solex in order that it could assess the commercial realities of the Harmattan Plant, both now and in the future, without having a new operator foisted upon it by the unilateral actions of the defendants.

The Court relaxed the usually strictly applied sequential tripartite test and followed the decision of Hunt J. (as she then was) in Debra's Hotels. The Court held that it could not be said that the balance of convenience favours the party that is in clear breach of a contractual covenant. To allow a party to breach a covenant would render the consent provisions of the Agreement meaningless. The Court was also not convinced that Solex's prospective plans for the Harmattan Plant would be jeopardized because of the interim injunction. The balance of convenience test favoured EMC and the maintenance of the status quo.

\section{COMMENTARY}

It is one of litigation counsel's worst nightmares to receive what has speciously become known as "come along notice" such as happened in this case, where the defendants (not their counsel) received three hours' notice of the application before Wilkins J. Often, counsel for the defendant would prefer not to receive any such notice at all, to avoid the application, through counsel's mere presence, being misconstrued as anything other than ex parte. In this case, counsel for NCLP and NCL made the difficult decision to appear on inadequate notice, and did his best under the circumstances to resist the application.

Notwithstanding the foregoing comments and the strictly applied rules of practice against ex parte applications, one cannot on the facts of this case fault the applicant's counsel for proceeding the way that they did. In certain emergency situations, counsel may, as a matter of good judgment, conclude that the time necessary for notice would seriously prejudice his client's rights and might render a nullity any action that the Court might take. For example, in this case, Park J. commented that the defendants purported to proceed with the closing of their assignment arrangements on 28 February 2002, more or less at the same time that the matter was being brought before Wilkins $\mathrm{J}$.

This case is useful to counsel for defendants in future actions, to the extent that it brings together all of the leading cases - particularly those pertaining to the petroleum and natural gas industry - that address the question of interlocutory injunctions. For plaintiffs' counsel, this case is a further elaboration of the principles enunciated by Hunt J. (as she then was) in Debra's Hotel concerning the circumstances where the normally strictly applied sequential tripartite test of American Cyanamide will be relaxed. Specifically, this case further defines 
what the parties must do to assert and defend allegations of an unequivocal breach of a clear contractual covenant.

\section{SPLIT TITLE}

\section{A. ANDERSON V. AMOCO CANADA OIL AND GAS 138 \\ l. BACKGROUND}

The "split title" lawsuits have been pending for many years. This case enunciates the basic principles to be applied in resolving these disputes.

\section{FACTS}

In 1912, the Canadian Pacific Railway (CPR), in granting land to settlers, began to reserve to itself "all coal, petroleum, and valuable stone."139 These reservations created "split title" lands, where one party owns the coal, petroleum and valuable stone (the Petroleum Owner) and the other party owns the other minerals (the Natural Gas Owner). These other minerals include natural gas, which when found in a reservoir with oil is, at the original virgin pressure and temperature, in one of two states: either in a gas cap above the oil in the reservoir, or in solution in a liquid state and mixed with the oil. When the reservoir is penetrated by a well and production realized, the pressure within the reservoir is reduced. Such reduction continues as the reserves are depleted. With that reduction in pressure, much of what was originally solution gas comes out of solution and becomes gaseous, both within the reservoir and as it proceeds to the surface. That so called "evolved gas" in the changed state in the reservoir and in the well-bore was primarily at issue in this case. The appellants derived their title from the Natural Gas Owner pursuant to such split title grants. The respondent derived its title from the Petroleum Owner.

The trial judge was asked to determine a preliminary issue as to the ownership of natural gas - a question that spawned 84 lawsuits. Hydrocarbons reside in the subsurface in three forms: oil reserves, gas reserve, and mixed reserves. Before a mixed reservoir is penetrated by drilling, the percentage of liquid and gaseous hydrocarbons is fixed (in engineering terms). Once the reservoir is drilled and extraction commences, phase changes occur, resulting in alteration to the percentages of liquid and gaseous substances.

The issue arose between the parties concerning the point at which a determination should be made as to the proportions of the total produced natural gas that belongs to the Petroleum Owner as opposed to the Natural Gas Owner. The respondent (Petroleum Owner) maintained that the ownership percentages should be determined under initial reservoir conditions. The appellants argued that the ownership should be determined as the gas is captured in the wellbore. 
The trial judge concluded that Borys v. CPR and Imperial Oil Led. ${ }^{140}$ as confirmed by Prism Petroleum Ltd. v. Omega Hydrocarbons Ltd., ${ }^{141}$ stands for the following propositions:

- the reservation was to be interpreted and title determined as at the time of the grant, at which time the hydrocarbons were at initial reservoir conditions; solution gas belongs to the Petroleum Owners; free gas or primary gas cap gas belongs to the Natural Gas Owners; and solution gas (evolved gas) that emerges from the liquid hydrocarbons in the reservoir, at the bottom of the well bore, at the surface, or anywhere in between, belongs to the Petroleum Owners;

- condensate and natural gas liquids which derive from primary gas cap gas belong to the Natural Gas Owners; and

- condensate and natural gas liquids which derive from the evolved gas belong to the Petroleum Owners.

\section{DECISION}

The Court held that the trial judge's conclusion that evolved gas, together with all solution gas that emerges at the surface, belongs to the Petroleum Owner was correct and consistent with the principles set out in Borys.

The Court also held that the trial judge did not misconstrue the relevant principles of property law. She correctly concluded that Canadian courts have not yet committed to a particular theory of oil and gas ownership. She properly acknowledged that petroleum does not have to be reduced to possession in order to become the subject of ownership. This was also evident from the decision in Borys, which declared ownership before the reservoir had been penetrated.

Although the trial judge did not specifically consider the meaning of the words, "which may be found to exist"142 as used in the reservation, the correctness of her decision was not undermined. At the time the CPR reservation was created, it was not known if petroleum existed below the surface of the land. Therefore, the reservation would only attach to petroleum that might be found to exist through exploration or production. Those words merely express a limitation on the operation of the reservation; however, they do not mean that the petroleum must be reduced to possession before it can be subject to ownership rights. Indeed, the same words appeared in the Borys reservation, and ownership was declared before possession.

The trial judge did not make a palpable or overriding error in her fact finding. In particular, she did not err in finding that the settled expectations of the industry are that solution gas is owned by the Petroleum Owner. Her finding was based on evidence concerning the regulatory environment in Alberta and the leasing arrangements made by the 
CPR as Petroleum Owner. Her finding was also supported by Borys, as confirmed by the Alberta Court of Appeal in Prism.

The Court of Appeal did not agree with the trial judge's conclusion that gas which emerges from connate water belongs to the Petroleum Owner. The reservation did not reserve water. Therefore, gas that was in solution within connate water at initial reservoir conditions was held not to belong to the Petroleum Owner.

Borys was authority for the proposition that ownership must be determined as at the time of the reservation. In this appeal, as in Borys, the hydrocarbons were at initial reservoir conditions at the date of the reservation. Phase changes that occurred subsequently were held to be irrelevant to ownership.

\section{COMMENTARY}

This case goes a long way towards settling at least the fundamental principles regarding the ownership of solution gas and evolved gas. There will, however, be ongoing disputes in the application of these principles. One example is Alberia Energyv. Goodwell Petroleum, ${ }^{143}$ where the Alberta Court of Appeal on 22 October 2002 granted leave to Alberta Energy (EnCana) to appeal a decision of the Alberta Energy and Utilities Board (AEUB) in which the AEUB ordered four high gas-to-oil ratio bitumen wells to be shut-in, pending resolution with the owner of the natural gas rights as to the question of ownership of the natural gas being produced in conjunction with the bitumen. The issues to be determined on that appeal will be whether the AEUB erred in deciding that EnCana's right to produce leased substances under its oil sands leases does not include any right to produce the initial gas cap gas and whether the AEUB erred in ordering the wells to be shut-in until such time as EnCana has "the full rights to produce" the gas cap gas. As is apparent from that case, and now that the fundamental principles are established, there remain significant questions of jurisdiction and enforcement of rights in relation to split title properties.

\section{CONFLICTS OF INTEREST}

\section{A. R. V. NEIL $L^{144}$ \\ I. BACKGROUND}

This case stems from a criminal appeal to the Supreme Court of Canada, yet is nevertheless instructive to all Canadian lawyers because it represents a further step in the evolution of conflict of interest principles applicable to lawyers.

\section{FACTS}

The appellant carried on a business in Edmonton as a paralegal for many years, and he was assisted by Helen Lambert. He regularly consulted "Pops" Venkatraman, a solicitor, about 
issues arising in his files. When advised by "Pops" that matters exceeded his competence, the appellant referred his clients to the Venkatraman law firm.

The conflict of interest in this case largely concerned the activities of Gregory Lazin, one of the Venkatraman firm's associates. Lazin shared office space and some facilities with the law firm in the fall of 1994. The trial judge found that as of 1 January 1995, Lazin should be considered a member of the Venkatraman firm for the purpose of conflict of interest and confidentiality, by virtue of the extended definition of "firm" adopted by the Law Society of Alberta. ${ }^{145}$

The appellant was charged over an alleged scheme to defraud Canada Trust. The appellant and his business associate, Helen Lambert, were said to have combined their efforts to obtain from Canada Trust mortgages on behalf of people whose credit-worthiness would have been rejected if their identity had been disclosed.

The conflicts of interest involving the Venkatraman firm came from two sources. First, the firm acted simultaneously for the appellant in the criminal proceedings and his business associate, Helen Lambert, in divorce proceedings at a time when they knew, or ought to have known, that she would also be charged in the Canada Trust criminal proceedings, with an interest adverse to his. Lazin sat in during a consultation that two of the members of the firm had with the appellant, with regard to the Canada Trust incident when he was under retainer from Lambert.

The second conflict of interest arose when Lazin was approached by Darren Doblanko, whose wife had obtained a divorce from him with the assistance of the appellant some years previously. She had relied on an affidavit of service on Darren Doblanko drafted by the appellant. The affidavit was false. At the suggestion of the trial judge in the Doblanko divorce, Lazin suggested to Doblanko that he report the misconduct to the police. Lazin steered Doblanko to the same police officer who was responsible for the Canada Trust file and other cases pending against the appellant.

\section{DECISION}

The Court discussed the lawyer's duty of loyalty, quoting O'Connor J.A. (as he then was) in R. v. McCallen ${ }^{146}$ as follows:

the relationship of counsel and client requires clients, typically untrained in the law and lacking the skills of advocates, to entrust the management and conduct of their cases to the counsel who act on their behalf. There should be no room for doubt about counsel's loyalty and dedication to the client's case. ${ }^{147}$

The Court said that the value of an independent bar is diminished unless the lawyer is free from conflicting interests. Loyalty, in that sense, promotes effective representation, on which

Law Society of Alberta, Code of Professional Conduct, looseleaf (Calgary: The Law Society of Alberta, 1995) at ix, online: Law Society of Alberta <www.lawsocietyalberta.com/info_lawyers/code/ conduct.asp>.

147 Jbid. at 67 . 
the problem-solving capability of an adversarial system rests. In MacDonald Estate $v$. Martin, ${ }^{148}$ Sopinka J. spoke of the "countervailing value that a litigant should not be deprived of his or her choice of counsel without good cause."149

The Court held that the duty of loyalty is intertwined with the fiduciary nature of the lawyer-client relationship. The lawyer fulfills squarely Professor Donovan Waters' definition of a fiduciary:

\begin{abstract}
In putting logether words to describe a "fiduciary" there is of course no immediate obstacic. Almost everybody would say that it is a person in whom trust and confidence is placed by another on whose behalf the fiduciary is to act. The other (the beneficiary) is entitled to expect that the fiduciary will be concerned solely for the beneficiary's interests, never the fiduciary's own. The "relationshijp" must be the dependence or reliance of the beneficiary upon the fiduciary. ${ }^{150}$
\end{abstract}

While the Court is most often preoccupied with uses and abuses of confidential information in cases where it is sought to disqualify a lawyer from further acting in a matter, the duty of loyalty to current clients includes a much broader principle of avoidance of conflicts of interest, in which confidential information may or may not play a role.

The Court referred to Drabinsky v. KPMG, ${ }^{131}$ where the plaintiff sought an injunction restraining the accounting firm KPMG (of which the plaintiff was a client) from further investigating the financial records of a company of which the plaintiff was a senior officer. Justice Ground, grouping together lawyers and accountants, said, "I am of the view that the fiduciary relationship between the client and the professional advisor, either a lawyer or an accountant, imposes duties on the fiduciary beyond the duty not to disclose confidential information. It includes a duty of loyalty and good faith and a duty not to act against the interests of the client." 132 The aspects of the duty of loyalty relevant to this appeal included issues of confidentiality in the Canada Trust matters, but also engaged three other dimensions:

- the duty to avoid conflicting interests, including the lawyer's personal interest;

- a duty of commitment to the client's cause (sometimes referred to as "zealous representation") from the time counsel is retained, not just at trial - that is, ensuring that a divided loyalty does not cause the lawyer to "soft peddle" his or her defence of a client out of concern for another client; and

- a duty of candour with the client on matters relevant to the retainer.

On learning that the appeliant's lawyer had put before the divorce court evidence of his further wrongdoing, the appellant understandably felt betrayed. Equally, the public in Edmonton, where the prosecution of the appellant had attracted considerable notoriety,

[1990] 3 S.C.R. 1235.

libid. at $1243,1265$.

D.W.M. Waters, "The Development of Fiduciary Obligations," in R. Johnson et al., eds., Gérard V. La Forest at the Supreme Court of Canada - 1985-1997 (Winnipeg: Canadian Legal History Project, 2000) 81 at 83.

(1978), 41 O.R. (3d) 565 (Gen. Div.).

Jbid. at 567. 
required assurance that the truth had been ascertained by an adversarial system that functioned clearly and without hidden agendas.

The general duty of loyalty has frequently been stated. In Ramrakha $v$. Zinner, ${ }^{153}$ Harradence J.A., concurring, observed,

A solicitor is in a fiduciary relationship to his client and must avoid situations where he has, or potentially may, develop a conflict of interests... The logic behind this is cogent in that a solicitor must be able to provide his client with complete and undivided loyalty, dedication, full disclosure, and good faith, all of which may be jeopardized if more than one interest is represented. ${ }^{154}$

The duty of loyalty was similarly expressed by Wilson J.A. (as she then was) in Davey $v$. Woolley, Hames, Dale \& Dingwall:

The underlying premise ... is that, human nature being what it is, the solicitor cannot give his exclusive, undivided attention to the interests of his client if he is torn between his client's interests and his own or his client's interests and those of another client to whom he owes the self-same duty of loyalty, dedication and good faith. ${ }^{155}$

The Court referred to the general rule that a lawyer may not represent one client whose interests are directly adverse to the immediate interests of another current client - even if the two mandates are unrelated - unless both clients consent after receiving full disclosure (and preferably independent legal advice), and the lawyer reasonably believes that he or she is able to represent each client without adversely affecting the other. The Venkatraman law firm was bound by this general prohibition to avoid acting contrary to the interest of the appellant, a current client, who was a highly vulnerable litigant in need of all the help and reassurance he could legitimately obtain. The Court held that the Venkatraman law firm put itself in a position where the duties it undertook to other clients conflicted with the duty of loyalty owed to the appellant.

\section{COMMENTARY}

In recent years, lawyers have been known to make the distinction between a so-called "professional conflict of interest" and a "business conflict." The distinction seems to be between a direct professional conflict of interest that clearly prevents a lawyer from acting, in the former case, and a conflict that may have business implications for the firm, in the latter. In the Neil case, the Supreme Court puts emphasis on the concepts of a lawyer's ethical duties of loyalty, dedication and good faith and emphasis on the obligation to provide undivided attention, full disclosure and absolute avoidance of any kind of a conflict of interest. Hopefully, this case will put an end to that specious concept that with a mere business conflict it is acceptable for a lawyer to undertake the brief. For most firms, and in particular those with a national and international presence, this case will add to the burden of grappling with conflicts of interest. Henceforth, however, the burden will be not so much in identifying what constitutes a conflict, since that now appears to have been more 
definitively described, but more from the point of view of fully identifying all possible conflicts, and then, hardest of all, dealing with them.

\section{TORTIOUS INTERFERENCE WITH CONTRACTUAL RELATIONS}

\section{A. VERCHERE V. GREENPEACE CANADA ${ }^{156}$ \\ 1. BACKGROUND}

Until this case, there was no economic disincentive to protestors interfering with the lawful operations of forestry (and by analogy, oil and gas) industry operations.

\section{FACTS}

A number of loggers, all of whom were members of the IWA Canada Local 2171 were employed by Hayes Forest Services Ltd. (Hayes) in various capacities to perform logging services on Roderick Island, off the coast of British Columbia. Hayes was in tum contracted to harvest timber by Western Forest Products Limited (Westem), the holder of the exclusive right to harvest timber from Roderick Island pursuant to Tree Farm Licence Number 25. The plaintiff loggers flew into the Roderick Island location in May 1997 to perform these services.

Coincidentally, commencing 20 May 1997, Greenpeace Canada and Greenpeace International staged ongoing protests on Roderick Island, disrupting the logging operations and preventing the plaintiffs from logging. Certain of the protestors hung protest banners on various pieces of equipment, while other protestors chained themselves to logging equipment. The camp manager made arrangements to fly the loggers off of Roderick Island the next day. The site chosen for the protest was integral to all logging operations on the island. Consequently, shutting down operations at the protest site effectively curtailed all logging operations on the island.

Between 20 May and 30 May 1997, the camp supervisor specifically asked Ms. Berman (one of the Greenpeace protestors) if the loggers could return to work. Ms. Berman invariably informed him that the protesters were not leaving, therefore the loggers could not return to work.

Hayes and Western commenced legal action to stop the interference by the protestors in the logging of Roderick Island. On 28 May 1997, the Court issued an injunction against the protestors. The injunction was served personally on the protestors, who withdrew from the worksite and left Roderick Island 30 May 1997.

At all material times, the plaintiff' employment arrangement with Hayes was the collective agreement negotiated by the IWA with Forest Industrial Relations Limited. Under that contract, workers were only paid for hours worked. 
The plaintiffs sued the individual protestors and Greenpeace Canada for tortious interference with their contractual relations with Hayes, in that the protestors' actions prevented the plaintiffs from performing their contractual obligations to Hayes to log Roderick Island.

The defendant protestors argued that their conduct was justified, with the predominant purpose in conducting the protests being to highlight Western's logging practices and to draw the world's attention to what they considered to be illegal and destructive logging practices, including shortcomings in the Forest Practices Code of British Columbia. ${ }^{157}$

\section{DECISION}

The Court found as fact that the defendant protestors did not know the details of the employment contracts between the plaintiffs and Hayes, but that this was not a defence. The plaintiffs established that the defendants knew or ought to have known that their conduct would interfere with the personal plaintiffs' contractual relations and that this was sufficient to establish liability. ${ }^{138}$ The union contracts were available through the union offices and the protestors had a duty to enquire into the particulars of those contracts. ${ }^{139}$ The protests prevented the plaintiffs from fulfilling their contractual obligations to Hayes, thereby causing the plaintiffs to lose employment income they otherwise would have earned. ${ }^{160}$

The Court also rejected the defendants' argument that the predominant purpose of the protestors was something other than the personal harm of the plaintiffs.

The Court awarded damages to each of the personal plaintiffs based upon the hours lost and the hourly rate of each plaintiff, with additional awards in respect of lost contributions to pensions directly relating to the stoppage of work.

\section{COMMENTARY}

There was no indication in this case that Hayes' logging operations on Roderick Island were being conducted contrary to the existing regulatory framework. Rather, the Greenpeace protest in large part was against the existing regulatory framework. To the authors' knowledge, this is the first case in which any civil sanction has been imposed upon non-violent protestors interfering with lawful resource industry operations. It should be noted, however, that the cause of action arose as a result of interference in the contractual relations between the individual loggers and the operating logging company. While analogous circumstances with oilfield contract workers exist in the oil and gas industry, overcoming the hurdle of express or imputed knowledge of the terms of the contract between the oilfield worker and his or her employer may be somewhat more difficult in the absence of union contracts. ${ }^{161}$ 